\title{
¿SACRILEGIO DEL DERECHO DE PROPIEDAD? FE PÚBLICA REGISTRAL Y FALSIFICACIÓN DE DOCUMENTOS
}

\section{SACRILEGE OF PROPERTY RIGHTS? PUBLIC FAITH IN REGISTRATION AND DOCUMENTS FORGERY}

\author{
Francisco Javier Escajadillo ${ }^{1}$ \\ Abogado \\ Universidad de San Martín de Porres \\ francisco.escajadillo@gmail.com
}

Perú

\section{SUMARIO}

- Introducción

- El derecho de propiedad

- Protección registral

- Análisis y discusión

- Conclusiones y propuestas

- Referencias

\section{RESUMEN}

Este artículo invita a reflexionar sobre la fe pública registral y el derecho de propiedad en los casos de fraude inmobiliario (falsificación de documentos o suplantación de identidades). En nuestro país, existen dos posiciones que parecen ser irreconciliables: Por un lado, quienes defienden la fe pública registral sobre el derecho de propiedad; por otro lado, quienes defienden el derecho de propiedad sobre la fe pública registral. Es importante asumir una de las dos posturas en esta confrontación, dado que solo a partir de la discusión académica será posible hallar una efectiva solución a este problema.

\section{ABSTRACT}

This article invites us to reflect on the public faith in registration and the property rights in the case of real estate fraud (falsification of documents or identities theft). In our country, there are two positions that seem to be irreconcilable: On the one hand, those who defend the public faith in registration above the property rights; on the other hand, those who defend the property rights above the public faith in registration. It is important to assume one of the two positions in this confrontation, because only from the academic discussion will be possible to find an effective solution to this problem.

\section{PALABRAS CLAVE}

Propiedad, registros públicos, apariencia jurídica, protección de terceros, fe pública registral, falsificación de documentos.

\section{KEYWORDS}

Property, public registry, legal appearance, protection of third parties, public faith in registration, falsification of documents.

\section{INTRODUCCIÓN}

En nuestro país, desde hace algunos años se ha acentuado una grave crisis institucional en cuanto a la efectiva protección del derecho de propiedad, considerado como uno de los derechos patrimoniales más importantes (Bullard, 2010, p. 36 y León, 2007, p. 50), así como la pierre angulaire de tuote civilisation (Delsol, 1878, p. 438).

Se suele relacionar el problema de esta grave crisis con la aplicación del principio de fe pública registral en los supuestos de 1 Abogado de la Subdirección de Administración del Patrimonio Estatal de la Superintendencia Nacional de Bienes Estatales del
Ministerio de Vivienda y Construcción. 
fraude inmobiliario. Dicha situación puede esquematizarse de una manera bastante sencilla: El propietario A es suplantado o se falsifica un documento en el que vende el inmueble $X$ al sujeto $\mathrm{B}$, tras inscribir dicha adquisición, $\mathrm{B}$ transfiere el inmueble $\mathrm{X}$ al sujeto $\mathrm{C}$, quien también inscribe su negocio adquisitivo. Entonces ¿es aplicable la protección de la fe pública registral en tales supuestos?

En este panorama, desde la doctrina se han esbozado distintas propuestas para su solución, mientras que, a nivel normativo, se han colocado parches que no logran más que disimular la gran fisura generada en el corazón mismo del derecho de propiedad, esto es, su inviolabilidad; sin embargo, a pesar de todos esos esfuerzos, no se está atacando el centro del problema.

Es evidente que todos somos responsables de que se haya mermado la garantía constitucional del derecho de propiedad, desde los operadores del sistema registral (Sunarp), pasando por los malos notarios hasta llegar a los propios administrados, que con sus actuaciones fraudulentas debilitan el sistema.

En este escenario, la defensa del derecho de propiedad suele hacerse a partir de su conceptualización, como si se tratara de un derecho sagrado; es decir, como si toda afectación al mismo se tratara de un sacrilegio (uno de estos es la fe pública registral). Este punto desemboca en la necesidad de analizar la problemática generada en torno a la falsificación de documentos y a la justificación para la aplicación (o inaplicación) del principio de fe pública registral. A su vez, es necesario efectuar un análisis de las instituciones jurídicas involucradas.

Por ello, primero abordaremos todo lo referente al derecho de propiedad y a su adquisición; luego desarrollaremos la protección que brinda el registro a los actos inscritos, su contenido y sus límites arcifinios. Finalmente, podremos efectuar un análisis preliminar del conflicto; y, como resultado de lo investigado, estableceremos las conclusiones y propuestas.

\section{EL DERECHO DE PROPIEDAD}

\section{La definición}

Si existe un derecho real par excellence es, sin duda, la propiedad. Tamaña categoría responde a que, dentro de la temática de los derechos reales, la propiedad es aquella que goza de un contenido más amplio (plena in re protestas). A su vez, es el punto de partida de los otros institutos comprendidos (desmembraciones ${ }^{2}$ ) dentro de la teoría general de los derechos reales, como son los accesorios, limitados o sobre bien ajeno ${ }^{3 \mathrm{y} 4}$ (ius in re aliena) denominados indistintamente.

Sin perjuicio de su origen indiscutiblemente civil, nuestro Tribunal Constitucional (TC), al referirse al derecho de propiedad, ha dejado establecido que es una garantía institucional, además de un derecho subjetivo constitucional. De ello, que el Estado se encuentre en la obligación de garantizar su inviolabilidad (sentencia recaída en el expediente N $.^{\circ} 00011-$ 2010-AI). Asimismo, para el TC, el derecho de propiedad tiene un doble carácter (sentencia recaída en el expediente N. ${ }^{\circ}$ 0030-2004-AI/ TC), ya que es un derecho subjetivo y, a la vez, es una institución jurídica objetiva portadora de valores y funciones. No solo eso: la propiedad es también expresión tanto de la libertad personal como de libertad económica (sentencia recaída en el expediente N. ${ }^{\circ} 03258-2010-A A$ ).

Lo mencionado permite afirmar que no estamos frente a un derecho subjetivo cualquiera. Todo lo contrario: estamos en presencia de un derecho fundamental cuyos contornos inciden transversalmente en todo nuestro ordenamiento jurídico. No es para menos, ya que el derecho de propiedad junto a la libertad de empresa son los pilares de nuestra economía nacional (art. $60 .^{\circ}$ de la Constitución), radicando en todo ello la importancia de su efectiva protección.

Fuera de nuestras fronteras, una destacable explicación sobre la necesidad de garantizar la propiedad la encontramos en Jean-Étienne Portalis $^{5}$ (2004) - conocido como uno de los redactores del Code Civil français-, quien en

2 Se afirma que cada derecho real accesorio, limitado o sobre bien ajeno es entendido como algún tipo de restricción al derecho de propiedad; es decir, se formulan como desmembraciones de la propiedad, ya sea que su origen provenga de la voluntad o por disposición legal (Álvarez, 1986, p. 18).

3 En la lógica de nuestro Código Civil, los derechos reales como el usufructo (art. $999 .^{\circ}$ ), uso y habitación (art. 1026..$^{\circ}$ ), superficie (art. 1030..$^{\circ}$ y las servidumbres (art. 1035..$^{\circ}$ ) se ubican dentro de lo que se ha denominado «Derechos Reales Principales», siendo un error, dado que dichos derechos reales se suelen definir en conjunto como derechos reales limitados, accesorios o sobre bien ajeno.

4 En la traducción al castellano de la obra de Louis Josserand, puede leerse que el autor hace la distinción entre diferentes categorías de derechos reales, ubicando así a (i) las desmembraciones, como el usufructo, uso, etc.; (ii) cargas de la propiedad, como las servidumbres; y, (iii) los derechos reales accesorios, como la hipoteca y otros derechos reales de garantía (Josserand, 1950, p. 21).

5 (1746-1807). 
su Discours préliminaire du premier projet de Code civil, señala:

\section{L'homme naît avec des besoins; il faut qu'il puisse se nourrir et se vêtir: il a donc droit aux choses nécessaires à sa subsistance et à son entretien. Voilà l'origine du droit de propiété.}

Personne n'aurait planté, semé ni bâti, si les domaines n'avaient été séparés, et si chaque individu n'eût été assuré de posséder paisiblement son domaine ${ }^{6}$ (p. 65).

El énfasis del autor en la importancia de garantizar adecuadamente la propiedad repercute en que ello permite que los individuos puedan internalizar correctamente las externalidades existentes, asumiendo directamente los costos y los beneficios de su actividad. Así, desde la perspectiva del Análisis Económico del Derecho, se generan incentivos para la inversión, ya que el régimen de propiedad privada permite evitar lo que Garret Hardin ${ }^{7}$ (1968) denominó The tragedy of the commons (La tragedia de lo común).

Si nos situamos en la perspectiva del sujeto de derecho, veremos que el derecho de propiedad es solo un subtipo comprendido dentro de una categoría teórica mucho mayor. Este, antes que derecho real, es un derecho subjetivo ${ }^{8 y 9}$. Por su parte, el derecho subjetivo se enmarca dentro de una categoría aun mayor denominada situaciones jurídicas subjetivas. Para entender bien los conceptos, de inicio precisaremos que las situaciones jurídicas son entendidas como «[...] situaciones de vida que tienen relevancia jurídica» (Pais de Vasconcellos, 2005, p. 631); mientras que las situaciones jurídicas subjetivas, stricto sensu, son «producto de la calificación jurídica de un interés» (Morales, 2011, p. 62).

\footnotetext{
6 Traducción libre: El hombre nace con necesidades; tiene que alimentarse y vestirse. Tiene, pues, derecho a las cosas necesarias para su subsistencia y su cuidado. He aquí el origen del derecho de la propiedad.

Ninguna persona hubiera plantado, sembrado ni edificado, si sus tierras no hubieran sido separadas, y si a cada individuo no se le hubiera garantizado la pacífica posesión de su territorio.

7 (1915-2003)

8 Se entiende por derecho real a un determinado tipo de derecho subjetivo que protege con carácter absoluto el interés de una persona sobre una cosa. (Díez Picazo, 2008, p. 81).

9 El profesor italiano Alberto Trabucchi (1967) explica respecto al derecho subjetivo que: «[el]1 titular de un derecho subjetivo puede parangonarse al hombre que tiene el poder de pulsar un interruptor de corriente eléctrica, aprovechándose de una fuerza ajena a él» (p. 53). Es así que afirma que el derecho subjetivo como prerrogativa proviene de una fuerza ajena a titular, que es conferida por el ordenamiento jurídico; dicha fuerza solo puede ejercerse una vez que el mismo derecho haya sido reconocido. Por ello, Doménico Barbero (1967) señala que el derecho subjetivo es «[el] 1 resultado de una protección jurídica actuada para todos por el derecho objetivo, por el ordenamiento jurídico» (p. 168).
}

Así, las situaciones jurídicas subjetivas pueden ser de ventaja (posición de preeminencia) o de desventaja (posición de subordinación). En nuestro caso, se suele entender el derecho subjetivo como la más importante situación jurídica subjetiva de ventaja activa (Roppo, 2007, p. 48). Le siguen el poder jurídico, entendido como la capacidad de producir determinadas consecuencias jurídicas (Zatti, 2005, p. 362) y la facultad, entendida como situación del sujeto de realizar lícitamente un acto (Nicolò, 2005, p. 111).

Atendiendo lo señalado, podemos advertir la imprecisión en la que incurre la definición normativa del derecho de propiedad contenida en el artículo 923. ${ }^{\circ}$ de nuestro Código Civil vigente (en adelante $\mathrm{CC}$ ), en cuanto señala que «La propiedad es un poder jurídico que permite usar, disfrutar, disponer y reivindicar un bien $[\ldots]$ » (subrayado añadido). Como ha sido establecido anteriormente, incluso por el propio $\mathrm{TC}$, estamos en presencia de un derecho subjetivo y no de un poder jurídico, ya que la categoría de los derechos subjetivos cumplen fundamentalmente una función sintética. Comprenden, en una sola definición, el elenco de prerrogativas de su titular, como su contenido, presupuestos y protección (Giardina, 2003, p. 145). Además, el derecho subjetivo es «[...] la forma jurídica de más intensa protección de un interés humano, en cuanto es la síntesis de una posición de fuerza y de una posición de libertad» (Nicolò, 2005, p. 109).

Sin perjuicio de ello, la definición normativa del actual art. 923. ${ }^{\circ}$ del CC es coherente con el pensamiento de sus redactores. Por un lado, Lucrecia Maisch Von Humboldt (1984, p. 11), miembro de la Comisión Reformadora del Código Civil de 1936, identifica como uno de los elementos constitutivos de los derechos reales al poder jurídico del titular. Por su parte, Jorge Avendaño Váldez (1980, p. 768), en el artículo $30 .^{\circ}$ de su anteproyecto al libro De los Derechos Reales, definió la propiedad en los mismos términos del texto vigente.

Es curioso que la definición normativa vigente de la propiedad diste mucho de su antecesora, dado que en el artículo $850 .^{\circ}$ del Código Civil de 1936 se puede leer que: «El propietario de un bien tiene derecho a poseerlo, percibir sus frutos, reivindicarlo y disponer de él dentro de los límites de la ley». Sobre dicho texto, Germán Aparicio y Gómez Sánchez (1942), un autor de la época, señaló que: 
El artículo 850, sin definir ese derecho ni fijar su contenido taxativamente, expresa las principales facultades que comprende o los grandes atributos que lo constituyen, que son: la posesión, la reivindicación, la libre disposición y la percepción de frutos. Todo enmarcado dentro de los preceptos establecidos por el legislador (p. 374).

En tanto, un conocido autor nacional afirma que la definición normativa de la propiedad no es precisamente uniforme en el derecho comparado (Gonzales, 2009, pp. 275-276). Así, señala que las definiciones contenidas en los distintos códigos civiles pueden clasificarse en dos tipos: (i) los códigos que siguen la tendencia del Code Civil des Français, promulgado en 1804 (art. 544..$^{\circ}$ ); y (ii) los códigos que siguen la tendencia del Bürgerliches Gesetzbuch (BGB) alemán, promulgado en 1896 ( $\S 903$ ), definiciones reproducidas a continuación:

\section{Code Civil}

Titre II. De la propiété

544. La propiété est le droit de jouir et disposer des choses de la manière la plus absolue, pourvu qu'on n'en fasse pas un usage prohibé par les lois ou par les réglemeus ${ }^{1}$.

\section{Bürgerliches Gesetzbuch}

Titel 1. Inhalt des Eigentums

$\S 903$. Eigentümer einer Sache der Kann, das Gesetz oder nicht soweit Rechte Dritter entgegensthen, mit der Sache nach Belieben Elle Verfahren Jeder von und andere Einwirkun gausschließen².

A partir de ello, es posible deducir que la definición normativa dada por el Code Civil français no es puramente descriptiva como se sostiene. Esto ya que el artículo $544 .^{\circ}$ del Code solo hace mención expresa al jouir y disposer, es decir, no se acoge una definición normativa de la propiedad fiel a los atributos que estudiaron los jurisconsultos romanos, como el ius utendi (uso), ius fruendi (disfrute), ius abutendi, (disposición) y el ius reivindicandi (reivindicación), a diferencia de nuestro Código Civil, que sí lo hace.

En la doctrina francesa, Charles Aubry ${ }^{10}$ y Charles-Frédéric Rau ${ }^{11}$ (1897), dos juristas

$10(1803-1883)$

$11(1803-1877)$ posteriores a la promulgación del Code, comentaron lo siguiente:

Les facultés inherentes à la propiété ne sont pas susceptibles d'une énumération détaillée. Elles se résument dans la proposition suivante: le propiétaire peut à volonté user et jouir de sa chose, en disposer matériellement, faire à son occasion tous les actes juridiques dont elle est susceptible, enfin exclure les tiers de toute participation à l'exercice de ces diverses facultés ${ }^{12}$ (p. 256).

Siguiendo la definición romanista de la propiedad y apartándose - aunque ligeramente - de la definición hecha por el Code, Jean-Joseph Delsol (1878) en su Explication Élémentaire du Code Civil, definía la propiedad como el derecho de «user (utendi), de jouir (fruendi) et de disposer (abutendi) d'une chose de la manière la plus absolue $[\ldots] \gg 2 \|^{13}$ (p. 439).

Por su parte, las definiciones que siguen la línea del BGB alemán son de carácter abstracto, es decir, omiten definir la propiedad sobre la base de la enumeración de sus atributos ${ }^{14}$. Sobre ello, Martin Wolff (1971) asegura que «la propiedad como derecho subjetivo no es idéntica a la suma de las facultades particulares en ella contenidas; en este sentido, se la puede definir como un derecho abstracto [...]» (p. 327). La influencia del derecho romano en el BGB es innegable; de ello que Eugéne Petit (1983) nos dice que «los jurisconsultos romanos no definen el derecho de propiedad, que, en efecto, escapa a toda definición por su sencillez y extensión [...]. Por eso, solo se limitan a estudiar los diversos beneficios que procura la propiedad» (p. 240).

De otro lado, el profesor peruano Freddy Escobar Rozas (2001) critica los atributos de la propiedad contenidos en la definición normativa del art. $923 .^{\circ}$ del CC, pues considera

12 Traducción libre: Las facultades inherentes a la propiedad no son susceptibles de una enumeración detallada. Ellas se resumen en la siguiente proposición: El propietario a su voluntad puede utilizar y disfrutar libremente de su cosa, disponer materialmente en cualquier ocasión de todos los actos jurídicos de los que es susceptible; finalmente, excluir a todos de la participación en el ejercicio de estas diversas facultades.

13 Traducción libre: usar (utendi), de disfrutar (fruendi) y de disponer (abutendi) de una cosa de la manera más absoluta [...].

14 En nuestro continente, por ejemplo, el artículo $2.507 .^{\circ} \mathrm{del}$ Código Civil argentino de 1869 acoge una definición no descriptiva (abstracta) del derecho de propiedad. 
que $«[\ldots]$ ni la facultad de disponer ni la de reivindicar forman parte del mismo [derecho]» (p. 106). Para arribar a dicha conclusión, inicia por diferenciar entre propiedad y titularidad; precisa que:
[...] la primera [propiedad] es una herramienta que permite desplegar un conjunto de comportamientos (sobre una cosa) para satisfacer determinadas necesidades (patrimoniales) del sujeto de derechos; la segunda [titularidad] es una herramienta que permite identificar a quién le corresponde la posibilidad de desplegar el referido conjunto de comportamientos (p. 109).

Sobre la base de dicha diferenciación, sostiene que:

\section{[...] las facultades de disposición y de reivindicación no pueden formar parte del contenido del derecho de propiedad. Con esto, obviamente, no pretendo afirmar que el propietario no pueda disponer o reivindicar, sino únicamente sostener que cuando aquel efectivamente dispone o reivindica, no hace otra cosa que "actuar" una situación jurídica subjetiva distinta al derecho de propiedad que le pertenece (p. 110).}

Así, entiende que «[...] la facultad de disponer no deriva del derecho de propiedad, sino de la relación de titularidad o pertenencia» (p. 112). Asimismo, señala con bastante lucidez que la reivindicación es «[...] un mecanismo de tutela del derecho de propiedad, esto es, una herramienta que el ordenamiento le otorga al titular de este derecho [...]» (p. 115). De ello que ni la disposición ni la reivindicación sean atributos propios del derecho de propiedad, sino de la titularidad establecida sobre dicho derecho.

No obstante, discutir sobre qué definición es la más adecuada solo nos lleva a un objetivo fútil. La importancia de estudiar el derecho de propiedad reside en analizar la utilidad del concepto. Así, en los términos señalados por el profesor italiano Stefano Rodotà (1986), «[...] son las técnicas de la propiedad las que resuelven el problema de los recursos escasos en términos de atribución del derecho a su utilización a algunos sujetos con exclusión de los demás» (p. 31). En esa línea de razonamiento, estamos convencidos de que la institucionalización de la propiedad es útil en la medida que otorga a su titular un efectivo poder de exclusión ${ }^{15}$.

En este punto, como bien lo señala Louis Josserand ${ }^{16}$ (1950), «la situación preponderante, omnipotente del dueño, es la resultante de la prohibición para los demás de tocar la cosa, de usurpar las prerrogativas de su legítimo propietario» (p. 103).

A partir de este poder de exclusión, como oponibilidad erga omnes, se suele entender la propiedad como un derecho absoluto, o mejor aún, en palabras del propio Louis Josserand (1950), «un poder absoluto es necesariamente exclusivo» (p. 103). En contraposición a esa tesis, existe un sector que niega el carácter absoluto del derecho de propiedad, considerando que su propio contenido social se impone como límite al ejercicio de sus atributos. Así, por ejemplo, el profesor de la Universidade de São Paulo Carlos Albertos Dabus Maluf (2007) afirma que «o direito de propiedade não mais se reveste do caráter absoluto e intangível, de que outrora se impregnava. Está ele sujeito, na atualidade, a numerosas limitações, impostas pelo interesse público e privado, inclusive pelos principios de justiça y do bem comum»» ${ }^{17}$ (p. 8).

Sin embargo, consideramos que se suele tener una lectura equivocada sobre la llamada absolutividad, ya que es expresada en esos términos con la finalidad de enfatizar en la fuerza excluyente que proviene de la propiedad. Incluso, el propio Louis Josserand (1950), luego de referirse al poder absoluto del titular del derecho de propiedad, reconoce que «todas las facultades jurídicas, por la razón de que se realizan en un medio social, comportan fatalmente límites; se encuentran comprimidas en nombre de situaciones, de aspiraciones igualmente respetables que reivindican su parte legítima [...]» (p. 103). Entonces, entender la propiedad como un poder absoluto no es contradictorio con respetar los límites objetivos que imponga el ordenamiento jurídico.

15 "La conclusión principal es que la propiedad debe permitir la exclusión más perfecta al menor costo posible, pero permitiendo, paralelamente, que los terceros estén en la posibilidad de conocer el derecho del que han sido excluidos" (Bullard, 2010, p. 165).

16 (1868 - 1941)

17 Traducción libre: "el derecho de propiedad no se reviste más del carácter absoluto e intangible, de que otrora se impregnaba. Él está sujeto, en la actualidad, a numerosas limitaciones, impuestas por el interés público y privado, inclusive por los principios de justicia y del bien común". 
Hasta este punto, queremos resaltar lo siguiente: el derecho de propiedad es uno de los más relevantes dentro de nuestro Estado Constitucional de Derecho. Ello hace que esté revestido por una esfera de protección especial, haciéndolo inviolable; sin embargo, la propia función social que cumple la propiedad se impone como un límite arcifinio del mismo derecho.

\section{Mecanismos de protección}

Como bien ha sido señalado por el filólogo norteamericano Robert Lefevre ${ }^{18}$ (2013) «la conducta que "debería" ocurrir no puede ser otra que aquella según la cual cada persona reconoce los derechos de propiedad de otra persona $[\ldots]$. En caso contrario, el concepto de propiedad privada no sería práctico y carecería de sentido» (p. 124). En ese sentido, la tutela de la propiedad a través de sus mecanismos de protección no es más que una respuesta frente a una conducta no deseada, dado que el escenario deseado no puede ser otro en el cual se respete el derecho de propiedad; sin embargo, en la medida en que eso no ocurre en la realidad, el ordenamiento jurídico tiene la obligación de contar con distintos mecanismos que garanticen a su titular el pleno goce de los atributos del derecho de propiedad. En palabras de un sector de la doctrina alemana representado por Westermann, Gurski y Erickmann (1998) «la atribución omnímoda de la cosa al propietario tiene como finalidad asegurarle el disfrute imperturbable de la misma» (p. 455).

Así, Luiz Guilherme Marinoni (2008) realiza una importante precisión a partir de una pregunta:

\section{¿Cuál es la razón de ser de las normas de protección? [...] Tales normas son dictadas a partir de la premisa que ciertas conductas deben ser evitadas. Sin embargo, para que el Estado cumpla efectivamente su deber de protección, no es suficiente la denominada protección normativa material, sino que es necesaria también la protección normativa procesal [...] (p. 63).}

Entonces, no solo basta la tutela del derecho material, sino que es necesaria la existencia del camino procesal que permita hacer efectiva la tutela material del derecho de propiedad. Solo con ello podrá cumplirse la afirmación que hace Alfredo Bullard (2011) cuando señala que:

$18(1911-1986)$

\begin{abstract}
La propiedad genera un "halo" protector que impide a los terceros desarrollar determinados comportamientos perturbadores con respecto al bien. Derivado de esta protección es que el propietario puede usar, disfrutar y disponer del bien [...]. Cuando el Código define propiedad, parecería definir facultades sobre el bien, pero en realidad lo que hace es señalar qué es lo que encontramos dentro del cerco que esta extiende (p. 344).
\end{abstract}

Sobre el esquema expuesto, es que nuestro ordenamiento jurídico ha previsto una serie de consecuencias jurídicas (mecanismos de protección) frente a la afectación del derecho de propiedad como son:

1. la prescripción adquisitiva de dominio (art. $950 .^{\circ}$ del CC);

2. la reivindicación (arts. $927 .^{\circ}, 979 .^{\circ}$ y $665 .^{\circ}$ del CC);

3. el remedio resarcitorio en los casos de afectación del derecho de propiedad (arts. 924. $.^{\circ}, 931 .^{\circ}, 934 .^{\circ}, 943 .^{\circ}, 945 .^{\circ}, 956 .^{\circ}$, $959 .^{\circ}, 960 .^{\circ}, 961 .^{\circ}, 962 .^{\circ}, 963 .^{\circ}, 975 .^{\circ}$ у 976. ${ }^{\circ}$ del CC);

4. la indemnización justipreciada dentro del esquema de la expropiación y la servidumbre minera (art. 928. ${ }^{\circ}$ del CC, art. $13 .^{\circ}$ del Decreto Legislativo $1192 .^{\circ}$ y Reglamento del artículo 7. ${ }^{\circ}$ de la Ley N. ${ }^{\circ} 26505$ aprobado por Decreto Supremo N. $\left.{ }^{\circ} 017-96-A G\right)^{19}$;

5. el deslinde o amojonamiento (art. $966 .^{\circ}$ del $\mathrm{CC})$

6. la facultad de cortar ramas o raíces de árboles vecinos que se extiendan sobre el predio (art. 967. ${ }^{\circ}$ del CC);

19 Hemos distinguido entre la obligación resarcitoria (remedio) en los casos de afectación del derecho de propiedad y la indemnización justipreciada dentro del esquema de la expropiación y la servidumbre minera. Ello, dado que tanto la indemnización como el resarcimiento son remedios de contenido y alcance distinto, a pesar que de ellos se haya hecho un uso sinonímico. Por un lado, la indemnización se impone por imperio de la ley, sin mayor verificación que la del hecho jurídico concreto en el supuesto de hecho normativo. Por otro lado, el resarcimiento es propiamente el remedio que el ordenamiento ha previsto para la reparación de daños en la responsabilidad aquiliana, lo que supone el análisis de la concurrencia de todos sus elementos como son el criterio de imputación, sea subjetivo (art. $1969 .^{\circ}$ del CC) u objetivo (art. 1970. ${ }^{\circ}$ del CC); el daño; y, la relación de causalidad, adecuada para la responsabilidad extracontractual (art. $1985 .^{\circ}$ del CC) y próxima para la responsabilidad contractual (art. 1321. del CC). 
7. la rectificación de áreas y linderos (arts. $504 .^{\circ}$ al $508 .^{\circ}$ del Código Procesal Civil y art. $13 .^{\circ}$ de la Ley N. ${ }^{\circ} 27333$ );

8. la duplicidad de partidas (arts. $56 .^{\circ}$ al $63 .^{\circ}$ del TUO del Reglamento General de los Registros Públicos, aprobado por Resolución del Superintendente $\quad$ N. ${ }^{\circ}$ 126-2012-SUNARPSN y la segunda disposición transitoria del Reglamento de Inscripciones del Registro de Predios, aprobado por Resolución del Superintendente N. ${ }^{\circ}$ 097-2013-SUNARP/SN);

9. el mejor derecho de propiedad (art. $1135^{\circ}$ del CC);

10. la fe pública registral (art. $2014 .^{\circ}$ del CC y art. VIII del TUO del Reglamento General de los Registros Públicos);

11. la tercería de $\operatorname{propiedad}^{20}$ (arts. 533. ${ }^{\circ}$ al 539. ${ }^{\circ}$ del Código Procesal Civil);

12. desalojo por ocupante precario (arts. $585 .^{\circ}$ al 596. ${ }^{\circ}$ del Código Procesal Civil) $)^{21}$;

13. la usurpación (art. 202. ${ }^{\circ}$ del Código Penal);

14. daño simple o agravado en un bien (arts. $205 .^{\circ}$ y $206 .^{\circ}$ del Código Penal);

15. el delito de estelionato (numeral $4 \mathrm{del}$ art. 197..$^{\circ}$ del Código Penal); y

16. falsificación de documentos e ideológica (art. $427 .^{\circ}$ y $428 .^{\circ}$ del Código Penal).

A través de este elenco de mecanismos de protección, se garantiza el respeto de la integridad del derecho de propiedad. Este no debe ser entendido en términos estrictos; por el contrario, proponemos una interpretación un tanto más flexible, dado que, por ejemplo, la expropiación se estructura como un supuesto de excepción de la inviolabilidad constitucional del derecho de propiedad; sin embargo, no

20 Sobre el particular, recientemente, en la sentencia del VII Pleno Casatorio Civil, recaida en la Casación N. ${ }^{\circ} 3671$ 2014-LIMA y publicada el 07 de diciembre de 2015 en el diario oficial El Peruano, se estableció que "el derecho de propiedad del tercerista es oponible al derecho del acreedor embargante, siempre que dicho derecho real quede acreditado mediante documento de fecha cierta más antigua que la inscripción del embargo"

21 En este tema específico, en la sentencia del IV Pleno Casatorio Civil, recaída en la Casación N. ${ }^{\circ}$ 2195-2011-UCAYALI, se estableció que "1. Una persona tendrá la condición de precaria cuando un inmueble ajeno, sin pago de renta y sin título para ello, o cuando dicho título no genere ningún efecto de protección para quien lo ostente, frente al reclamante, por haberse extinguido el mismo". representa per se un acto arbitrario debido a que se restringe a causas específicas y, además, condiciona su realización (carácter forzoso) al previo pago de la indemnización justipreciada (hoy también conocida como tasación ${ }^{22}$ ). Ocurre exactamente lo mismo en el caso de la imposición de una servidumbre administrativa, como la servidumbre minera. Solo podría considerarse arbitrario un escenario en el cual el Estado adquiere derechos de propiedad privada sin pagar nada a sus titulares.

\section{Configuración del hecho adquisitivo}

En términos generales, toda norma jurídica se compone por un supuesto de hecho y una consecuencia jurídica. Así, el supuesto de hecho, como hecho jurídico hipotético, es el criterio que permitirá establecer la aplicabilidad de la consecuencia jurídica. Los derechos subjetivos, como la propiedad, son propiamente efectos jurídicos, dado que la norma es la que establece los supuestos en los cuales se puede reputar propietario a un sujeto. En esa línea de razonamiento, será la propia norma la que señalará el hecho que deberá producirse en la realidad para que se ligue el efecto de la adquisición de la propiedad de un bien, lo que denominaremos «hecho adquisitivo».

La profesora de la Universidad Autónoma de Barcelona, María del Carmen Gete-Alonso (1997, pp. 431-434) ha dedicado unas líneas al nacimiento de los derechos subjetivos. Indica que dicho fenómeno jurídico ocurre con la producción del hecho real al que el ordenamiento jurídico liga tal efecto, tras concurrir todos los presupuestos y requisitos que se exigen en cada caso concreto. Partiendo de ello, dicha autora analiza los modos de adquisición de derechos subjetivos según los siguientes criterios:

- Eficacia reconocida a la voluntad humana: (i) adquisición ex lege (efecto adquisitivo no depende de la voluntad); y (ii) adquisición voluntaria o negocial (efecto adquisitivo tiene su fuente en la voluntad).

- Dependencia o independencia de la situación jurídica: (i) originaria o ex novo (sin relación de causalidad con una situación jurídica anterior); y (ii) derivativa (con relación de causalidad con la anterior situación jurídica).

22 (Decreto Legislativo N. ${ }^{\circ} 1192$ ) Artículo $13 .^{\circ}$. Fijación del valor de la tasación

(...) 13.4. En el proceso de expropiación, la indemnización justipreciada es el valor de la tasación, constituyendo el precio a pagarse por todo concepto al sujeto pasivo. 
- Formación del supuesto de hecho: (i) adquisición instantánea (simultaneidad entre la producción del hecho y la adquisición del derecho); y (ii) adquisición sucesiva (ocurrencia de un hecho jurídico complejo o de varios).

Así, nuestro Código Civil establece los cinco hechos adquisitivos siguientes: (i) la apropiación (art. 929. ${ }^{\circ}$ del CC); (ii) la especificación y mezcla (art. 937. ${ }^{\circ}$ del CC); (iii) la accesión (art. 938..$^{\circ}$ del CC); (iv) la transferencia (art. $947.0^{\circ}$ y $949 .^{\circ}$ del CC); y (v) la prescripción adquisitiva de dominio (art. $9500^{\circ}$ del CC).

Siguiendo ese esquema, la apropiación es una adquisición de tipo voluntaria, originaria e instantánea; la especificación y mezcla es un tipo de adquisición ex lege, originaria e instantánea; la accesión es una adquisición de tipo ex lege, originaria e instantánea; la transferencia de la propiedad, vía tradición o contrato, es de tipo voluntaria, derivativa e instantánea; finalmente, la prescripción adquisitiva de dominio es un tipo de adquisición ex lege, originaria y sucesiva.

En el Capítulo Segundo que forma parte del Título II y de la Sección Tercera del Libro V de nuestro Código Civil, no solo se establecen los supuestos de adquisición de la propiedad, sino también los límites para dichos supuestos e, incluso, hechos que no configuran propiamente una adquisición. Pensemos por un momento en la apropiación, que solo puede darse sobre cosas libres (res nullius). Así, a pesar de que nuestro CC enuncia qué cosas son consideradas libres, v. gr., las piedras, conchas y cosas análogas que se hallen en el mar, ríos, playas u orillas (art. 929. ${ }^{\circ}$ del CC), los animales de caza y peces; sin embargo, si la actividad de caza o pesca de animales se realiza en un predio ajeno y sin autorización del dueño o poseedor, no se adquiere la propiedad de los animales cazados o pescados (art. 930..$^{\circ}$ y $931 .^{\circ}$ del CC). Del mismo modo, tanto en el caso de hallazgo de objetos perdidos (por su ubicación, un supuesto de apropiación), como en la búsqueda y/o descubrimiento de tesoros en terrenos ajenos cercados, sembrados o edificados, siempre que no se cuente con autorización del propietario, tampoco se configurará el hecho adquisitivo. Esta regla es tan sólida que, incluso en caso de enajenación, vía traditio, de un bien mueble perdido, a pesar de que exista buena fe del adquiriente (supuesto en el que se protege la apariencia del derecho), se desprende que este último no adquiere la propiedad (art. $948 .^{\circ}$ del CC).

Sin perjuicio de lo que ha sido mencionado, nos centraremos en el hecho adquisitivo más usual y que, además, es esencial en nuestro trabajo: la transferencia de la propiedad de bienes inmuebles por medio del contrato.

Con la finalidad de tener presente la distinción, para el caso de los bienes muebles, el Código es claro cuando señala que se adquiere la propiedad por medio de la tradición; es decir, la posesión del bien aunada a la voluntad de enajenarlo configuran el hecho adquisitivo (art. 947..$^{\circ}$ del CC). En el caso de los bienes inmuebles, no ocurre lo mismo; ello responde a que nuestro artículo $949 .^{\circ}$ del CC señala que la propiedad se adquiere con la sola existencia de la obligación de enajenar, siendo la existencia de dicha obligación (el hecho adquisitivo) lo que se suele identificar como el sistema consensual de transferencia de la propiedad.

En este punto, es necesario precisar que en el derecho comparado se reconocen básicamente tres sistemas de transferencia de propiedad: En el primero, se sigue la tradición romana, según la cual se requiere del título (acuerdo) y el modo (tradición) 23 para transferir la propiedad; en el segundo, siguiendo el Code francés, la transferencia de la propiedad opera con el solo contrato de transferencia, conocido como el sistema de transferencia consensual, espiritual o de unidad del contrato ${ }^{24}$; en el tercer sistema,

23 "Primitivamente, estos modos eran tres: la mancipatio y la in jure cesio para la res mancipi; la traditio para las res nec mancipi. Posteriormente los dos primeros modos fueron abolidos y quedó solo la tradición como modo de transmisión de la propiedad [...]. La idea esencial del sistema era que la voluntad de las partes podia bastar para el perfeccionamiento del contrato, porque este creaba obligaciones y derechos únicamente entre ellas; pero esa voluntad no era suficiente para crear el derecho real de propiedad, porque tratándose de un derecho oponible a todos los miembros de la sociedad (erga omnes), su creación solo podia tener lugar con intervención y conocimiento de ellos" (Salvat, 1946, p. 495).

24 «En el Derecho francés antiguo continuó acentuándose la espiritualización de la transferencia de dominio que ya se había iniciado en el Derecho Romano. Se fue introduciendo poco a poco la práctica de agregar en los contratos una cláusula llamada dessaisine-saisine (desposesión-posesión) en cuya virtud el enajenante declaraba haber abandonado la posesión de la cosa en manos del adquiriente, quien a su vez declaraba haberla recogido. [...] la tradición, todavía indispensable para operar la transferencia de propiedad, se convirtió por obra de la cláusula dessaisine-saisine en un modo absolutamente espiritual [...]. El uso de esta cláusula fue generalizándose a tal punto que con el tiempo se convirtió en una cláusula de estilo y se la consideró sobreentendida en todos los contratos aunque no hubiese sido expresamente consignada" (Forno, 1993, pp. 80 y 81). 
siguiendo al BGB alemán, la transferencia de propiedad se basa en un sistema abstracto ${ }^{25}$, en que la propiedad se adquiere con la inscripción registral.

Como puede desprenderse, nuestro ordenamiento jurídico para la transferencia de la propiedad de bienes inmuebles se ha acogido al modelo francés. Sin embargo, es importante recordar lo que señaló Lucrecia Maisch Von Humboldt (1980) en su anteproyecto al libro Los Derecho Reales respecto a la transmisión inmobiliaria:

La transmisión inmobiliaria es un arduo problema en países como el Perú, que no tienen el sistema catastral germánico [...]. Como es conocido, este problema se planteó en el seno de la comisión codificadora de 1936, en la que surgieron dos tendencias: los Doctores Solf y Oliveira propugnaban un sistema dual, en el sentido que fuera obligatoria la inscripción referente a inmuebles registrados y facultativa para los demás; por otro lado, los Doctores Calle y Olaechea consideraban que era muy peligrosa tal dualidad, inclinándose por el mantenimiento del sistema imperante, no sin lamentarlo, ya que reconocían sus defectos. (p. 853)

En el mismo anteproyecto, concluía sobre el tema lo siguiente:

Desde la promulgación del Código [1936] la inscripción en el Registro de la Propiedad Inmueble se ha generalizado y extendido en forma notable, no solo por las indudables ventajas y seguridades que brinda, sino también por exigencias de orden legislativo, como las de la Ley del Banco Hipotecario del Perú, la de la Reforma Agraria, etc.

Por estas razones, y siendo el problema de tanta trascendencia, la Comisión encargada del estudio y revisión del Código Civil debería abocarse al estudio

25 "Por los primeros [negocios obligacionales] se crean vínculos de obligación que sirven de fundamento o base causal de la transmisión o de la alteración del derecho real que, de manera efectiva, solo se lleva a cabo mediante el negocio dispositivo. Este es el que verdaderamente genera la titularidad real [...] Supone pues, una absoluta delimitación entre los negocios que tienen eficacia inter partes y aquellos otros que generan una eficacia erga omnes. [...] Asi surge la noción de acto de disposición (Verfügung) desligada del contrato, y ello de forma absoluta por la naturaleza abstracta (no causal) del mismo" (Cuena, 1996, p. 182). de esta materia, sopesando las razones en pro y en contra y la posibilidad de adoptar el sistema TORRENS en el Perú, tal vez en forma paulatina y progresiva [...] ( $p p$. 853 y 854).

Años más tarde, en el libro que la misma autora tituló Los Derechos Reales, efectivamente reconocía las bondades del sistema registral en cuanto a la transferencia de propiedad, siendo más seguro y mucho mejor que el vigente; sin embargo, al no ser ajena a la realidad de nuestro país, solo se limitó a demostrar sus deseo de que algún día se implante en el Perú el registro constitutivo de derechos (Maisch, 1984, p. 57).

Como puede apreciarse, si bien mantenemos la tradición francesa para la transferencia de inmuebles, desde hace casi un siglo nuestros codificadores han reconocido como desiderátum la adopción en nuestro país tanto del sistema alemán como del Torrens (seguro de títulos).

Sin perjuicio de lo que hemos mencionado, es necesario introducir someramente en nuestro discurso cuál fue el contexto en el que se forjó el art. $1138 .^{\circ}$ del Code, el mismo que es el formante legislativo de nuestro actual art. 949. ${ }^{\circ}$ del CC. Como se sabe, en el derecho francés antes se seguía el principio del título y modo para la transferencia de bienes inmuebles, sin embargo, de acuerdo con la explicación de Charles Aubry y Charles-Frédéric Rau (1897), se sabe que:

Ces príncipes [título y modo], admis en théorie dans les pays de Droit écrit-et même dans la majeure partie des pays coutumiers. Avaient été profondément modifiés, du moins en matière immobilière, par les effets que la pratique, d'accord avec les dispositions de quelques coutumes, attachait à la clause de dessaisine-saisine insérée dans les actes notariés, en assimilant la simple déclaration de tradition, résultant de cette clause, à la tradition, du Droit romain, qui supposait un déplacement réel de la possession. $(p .420)^{26}$

26 Traducción libre: Estos principios, en teoria permitidos en los países de derecho escrito, e incluso en gran parte de los países costumbristas, habian sido cambiados profundamente, al menos en materia inmobiliaria, para los efectos de la práctica, según las disposiciones de algunas costumbres, unido a la cláusula de desposesiónposesión insertadas en los actos notariales, asimilando la simple declaración de tradición que resulta de esta cláusula a la tradición del Derecho romano que suponia un desplazamiento real de la posesión. 
Lo citado representa la clara explicación del contexto en el cual se forjó la supresión de la traditio como modo de adquirir el dominio, y se gestó la unificación del conocido título y modo, reemplazando la entrega real de la cosa (modo) por la suscripción de la cláusula dessaisine-saisine (Escobar, 2004, p. 223 y Josserand, 1950, p. 263). Así, mientras el art. $1138 .^{\circ}$ del Code tiene por tenor lo siguiente: «L'obligation de livrer la chose est parfaite par le seul consentement des parties contractantes $[\ldots] \gg^{27}$, nuestro art. 949. ${ }^{\circ}$ establece que: $« \mathrm{La}$ sola obligación de enajenar un inmueble determinado hace al acreedor propietario de él, salvo disposición legal diferente o pacto en contrario».

En el derecho francés, la consagración legislativa de esta práctica jurídica se consideró como «uune importante innovation aux principies du droit romain et de l'ancien droit français. Autrefois, la translation de la propiété n'avait lieu que par la tradition; encore la tradition n'était-elle pas toujours suffisante» (Delsol, 1878, p. 442) (28 $^{28}$

Por su parte, en nuestro país se ha llegado a sostener que el sistema consensual reduce significativamente los costos de transacción al no requerir gasto en notarios, escrituras públicas ni costos de inscripción (Fernández, 1994, p. 171). Empero, frente a dicho argumento se ha opuesto el hecho de que se obvia el alto costo que la incertidumbre produce en este tipo de transacciones (Bullard, 2010, p. 190). Prácticamente, estamos frente a la discusión planteada para el Proyecto del Código Civil de 1936 entre Oliveira y Solf y Muro contra Olaechea y Calle.

Así bien, es necesario referirnos a que la obligación de enajenar, a la que hace alusión el artículo $949 .^{\circ}$ de nuestro Código Civil, solo puede tener como fuente a las que nuestro ordenamiento jurídico le otorga tal efecto. En este punto, nos vemos obligados a efectuar un necesario deslinde, pues en los supuestos de institución de herederos forzosos o voluntarios, o bien de legatarios, consideramos que no

27 Traducción libre: La obligación de entregar la cosa se perfecciona por el solo consentimiento de las partes contratantes $[. .$.$] .$

28 Traducción libre: Una importante innovación con los principios del derecho romano y del antiguo derecho francés. Anteriormente, la trasmisión de la propiedad se producia solo por la tradición; sin embargo, la tradición no siempre era suficiente. se configura propiamente una obligación de enajenar. Ello por el simple hecho de que, si bien el testador, a través del negocio jurídico testamentario y en ejercicio pleno de su autonomía privada, decide la distribución de su patrimonio, no se genera una obligación de enajenar, sino solo en cuanto a la continuidad de la propiedad ${ }^{29}$. Esto se refuerza, además, en el supuesto que el testador (en vida), decida vender el inmueble con posterioridad al testamento; la venta misma sustrae el bien vendido de su patrimonio $\mathrm{y}$, en consecuencia, los efectos post-mortem no lograrán producirse $^{30}$.

En nuestro ordenamiento, la obligación de enajenar es consecuencia de una relación contractual y no puede ser analizada de forma aislada, sino atendiendo a su naturaleza sistemática. El documento y su exigencia en cuanto al tipo de documento se ubican propiamente en la forma de los negocios jurídicos. Al respecto, nuestra legislación ha dejado por sentado que, si bien existe libertad de forma (art. 143. ${ }^{\circ}$ del CC), cuando en la ley se haga explícito el uso de determinada forma y su inobservancia no sea sancionada expresamente con la nulidad del negocio jurídico, solo constituirá un medio de prueba de que el negocio jurídico existe (art. 144. ${ }^{\circ}$ del CC); eso se conoce como forma ad probationem. Por el contrario, cuando la inobservancia de la forma se sanciona expresamente con la nulidad del negocio jurídico (numeral 4 del art. $140 .^{\circ}$ del CC), la forma es conocida como ad solemnitatem ${ }^{31}$, dado que es un presupuesto esencial para su existencia. Un aspecto adicional a lo que venimos mencionando es lo señalado por Rómulo Morales Hervias (2011, pp. 228-229), quien diferencia entre formalidades legales obligatorias y la formalidad convencional obligatoria.

29 "La sucesión es la sustitución de la persona titular del derecho por otra persona que pasa a ocupar su lugar, permaneciendo inalterado el derecho". (Gete-Alonso, 1997:435).

30 Basta verificar lo que dispone el artículo 98. del Reglamento de Inscripciones del Registros de Predios, aprobado por Resolución del Superintendente Nacional de los Registros Públicos N. ${ }^{\circ}$ 097-2013-SUNARP/SN, cuyo tenor indica que: "Las transferencias a favor de terceros efectuadas por el causante antes de su fallecimiento, podrán inscribirse aun cuando en la partida registral del predio se hubiera inscrito la sucesión a título universal, siempre que su inscripción no perjudique a terceros".

31 En nuestra jurisprudencia, este tema ha sido tratado, por ejemplo, en la Casación N. ${ }^{\circ}$ 2565-98-LIMA, la N. ${ }^{\circ} 1368-99-$ LIMA, la N. ${ }^{\circ} 1618-99-L I M A$ y en la N. ${ }^{\circ} 240-2013-J U N I N$. 
Dentro de ese razonamiento y por regla general, el contrato (entendido como acuerdo) se perfecciona cuando ambas partes están conformes con su contenido (art. $1352 .^{\circ}$ del CC) y se cumplen los requisitos de validez del acto o negocio jurídico (art. $1400^{\circ}$ ). Contrario sensu, sin acuerdo de las partes simplemente no existe contrato (art. $1359 .^{\circ}$ ). Asimismo, un acto o negocio jurídico que no cumple con los requisitos para su validez, es inválido. Para el caso específico de la compraventa, consideramos oportuno transcribir un extracto de la Casación N. ${ }^{\circ} 1368-99-J U N I ́ N$ en la que se señala:

Quinto. Que, es facultativo que el contrato decompraventaconsteenescriturapública, para cumplir con el requisito del artículo $4 .^{\circ}$ del Reglamento de Inscripciones de los Registros Públicos, siendo de aplicación lo dispuesto en el artículo $14122^{\circ} \mathrm{del}$ Código Civil, desde que el otorgamiento de la escritura pública en este caso no reviste un requisito ad solemnitatem, esto es que se haya convenido que la escritura pública es requisito indispensable para la validez del acto, bajo sanción de nulidad.

Es similar el caso de la permuta, dado que se le aplican las reglas sobre compraventa en cuanto lo sean (art. 1603. ${ }^{\circ}$ del CC). En la que sí se encuentra una marcada diferencia es en cuanto a la donación, dado que por mandato expreso del artículo $1625 .^{\circ}$ del CC, «la donación de bienes inmuebles debe hacerse en escritura pública $[. .$.$] bajo sanción de nulidad».$

De lo que hemos señalado, podemos extraer una importante conclusión: la configuración del hecho adquisitivo tiene relación directa con la validez de la causa adquisitiva; si la causa adquisitiva es inválida, simplemente, no se configura el hecho adquisitivo. La razón es sencilla: el artículo $9490^{\circ}$ del CC habla de una obligación de enajenar. Dicha obligación solo puede tener como fuente los hechos jurídicos que el propio Código Civil identifica como «fuente de las obligaciones». Para el caso específico de la transferencia de bienes inmuebles, dentro de ellos tenemos a la compraventa (arts. $1529 .^{\circ}$ al $1601 .^{\circ} \mathrm{del}$ CC), a la permuta (arts. $1602 .^{\circ}$ y $1603 .^{\circ}$ ) y a la donación (arts. 1621..$^{\circ}$ al $1647 .^{\circ}$ del CC). En estricta relación de consecuencia, no existe la denominada «obligación de enajenar» si la fuente de dicha obligación (el contrato) es inválida.
En nuestra doctrina nacional se hace mención sarcástica de un nuevo modo de adquirir la propiedad: la falsificación (Gonzales, 2015). A pesar de que el nombre sea impreciso, entendemos el objetivo del título que colocó su autor.

Como hemos mencionado, los hechos adquisitivos conforman una lista cerrada dentro de la lógica de nuestro ordenamiento jurídico. La falsificación es un hecho jurídico aparente que nace del fraude; sin embargo, se subsume dentro de la fenomenología de los hechos adquisitivos. Viéndose así las cosas, la falsificación no es un modo de adquirir (en estricto) la propiedad; todo lo contrario, es un modo de simular el hecho adquisitivo cuando este, en la realidad de los hechos, no existe. Evidentemente, pueden identificarse fácilmente contradicciones en nuestro sistema cuando se otorga protección al adquiriente $\mathrm{y}$ tercer adquiriente de estos supuestos. Sin perjuicio de ello, no es coherente gastar pólvora en el mecanismo de protección cuando ni siquiera se brindan soluciones para el origen del problema.

\section{Función del registro en el hecho adquisitivo}

Como hemos visto, el hecho adquisitivo se configura de diversas formas: en algunos casos con total independencia de los documentos que sirven para probarlo (como en la compraventa y la permuta); en otros casos, con total dependencia, dado su carácter solemne (el caso de la donación). No obstante, en ningún supuesto se exige la inscripción registral como elemento de validez del contrato, por lo que la transferencia de la propiedad en nuestro ordenamiento jurídico opera como efecto de un contrato válido.

Entonces, sería necesario establecer cuál es la función que cumple el registro en relación con el hecho adquisitivo. En el caso peruano, la inscripción registral tiene efecto meramente declarativo. Como consecuencia de la inscripción, el derecho de propiedad cuenta con la protección que deviene del registro ${ }^{32}$,

\footnotetext{
32 "El registro es el mayor signo de recognoscibilidad que se conoce. Este se caracteriza por ofrecer una información perfecta respecto de los sujetos titulares de derechos. Debemos aclarar que al aludir a información perfecta nos estamos refiriendo a los efectos absolutos que el ordenamiento da al contenido de las inscripciones, incluso en el caso que esa información no esté de acuerdo con la realidad". (Hernández, 1993, p. 189)
} 
además de una tutela extrarregistral propia del Derecho civil. Esta protección muchas veces es entendida a partir de la oponibilidad y es la que ocupa una posición privilegiada en cuanto a la prevalencia de lo inscrito en cualquier escenario de conflicto (arts. 665. $.^{\circ} 2,912 .^{\circ}$, $914 .^{\circ}, 1128 .^{\circ}, 1135 .^{\circ}, 1584 .^{\circ}, 1591 .^{\circ}, 1670 .^{\circ}$, $1708.1 .^{\circ}, 2014 .^{\circ}, 2022 .^{\circ} \S 1$ y $\left.2038 .^{\circ}\right)$. Es decir, en relación con el hecho adquisitivo, la función del registro es brindar un nivel de tutela adicional y preferente. Así, si enfrentamos un derecho de propiedad inscrito y uno no inscrito, prevalecerá el inscrito, ya que el escenario deseado no puede ser otro en el cual el derecho de propiedad esté dotado de cognoscibilidad, siendo este aspecto el que deviene del registro.

Por el contrario, no es posible sostener que el derecho de propiedad no cuente con efectivos mecanismos de tutela cuando no esté registrado. Basta recordar lo decidido en el VII Pleno Casatorio Civil respecto a la primacía de la propiedad no inscrita adquirida con anterioridad a la inscripción del embargo.

\section{PROTECCIÓN REGISTRAL}

\section{E1 acceso al registro y la dinámica de los principios registrales}

Como no podría ser de otra forma, nuestro sistema registral se construye sobre la base de garantías y principios registrales. Las garantías del sistema registral son detalladas por el artículo $3 .^{\circ}$ de la Ley N. ${ }^{\circ} 26366$ que crea el Sistema Nacional de los Registros Públicos (Sinarp) y la Superintendencia Nacional de los Registros Públicos (Sunarp). Para el tema que nos ocupa, solo mencionaré dos garantías: (i) la intangibilidad del contenido de los asientos registrales, salvo título modificatorio o sentencia judicial firme; y (ii) la seguridad jurídica de los derechos de quienes se amparan en la fe del registro.

Por otra parte, los principios registrales se ubican tanto en el libro IX del Código Civil, dedicado a los registros públicos, como en el título preliminar del TUO del Reglamento General de los Registros Públicos.

Tanto las garantías como los principios son el sostén de todo el Sinarp; de ahí que ostente un rol protagónico respecto a la seguridad jurídica. Además, se encuentran presentes en diversas etapas de los procedimientos de inscripción y en lo referente a la protección de lo inscrito. Para graficar un poco lo mencionado, tomaremos la inscripción de un contrato de compraventa de predio como ejemplo, con la finalidad de identificar el ámbito de actuación concreta de los principios registrales contenidos en el título preliminar del Texto Único Ordenado del Reglamento General de los Registros Públicos, aprobado por Resolución del Superintendente Nacional de los Registros Públicos N. ${ }^{\circ}$ 126-2012-SUNARP-SN. Veamos:

- La solicitud que se suscribe y los documentos que se anexan representan la actuación concreta de los principios registrales de rogación ${ }^{33}$, titulación auténtica ${ }^{34}$ y especialidad ${ }^{35}$. Ello puesto que en la mencionada solicitud de inscripción se consigna el nombre del solicitante, el acto que se desea inscribir, el registro a que corresponde y la relación de documentos que sustentan la solicitud de inscripción.

- Una vez adjuntada la documentación y tras efectuar el pago del arancel correspondiente se genera el asiento de presentación ${ }^{36}$, determinándose así la actuación de la prioridad registral ${ }^{37}$, sea excluyente $o$ preferente.

- Luego de ello, se procede a efectuar la calificación registral, por lo que se verifican distintos elementos del acto rogado, tanto

33 «III. Principio de rogación y de titulación auténtica

Los asientos registrales se extienden a instancia de los otorgantes del acto o derecho, o de tercero interesado [...] La rogatoria alcanza a todos los actos inscribibles contenidos en el título, salvo reserva expresa [...]".

34 "III. Principio de rogación y de titulación auténtica Los asientos registrales se extienden [...] en virtud del título que conste en instrumento público, salvo disposición en contrario".

35 "IV. Principio de especialidad

Por cada bien o persona jurídica se abrirá una partida registral independiente, en donde se extenderá la primera inscripción de aquellas así como los actos o derechos posteriores relativos a cada uno [...]".

36 "Artículo $19 .^{\circ}$ Asiento de presentación

Los asientos de presentación se extenderán en el Diario por riguroso orden de ingreso de cada título.

El asiento de inscripción se extiende en mérito de la información contenida en la Solicitud de Inscripción. Complementariamente, podrán obtenerse del título presentado datos adicionales, siempre y cuando estos no cambien el sentido de la información principal contenida en la citada solicitud $[\ldots]$ ".

37 "IX. Principio de prioridad preferente Los efectos de los asientos registrales, asi como la preferencia de los derechos que de estos emanan, se retrotraen a la fecha y hora del respectivo asiento de presentación, salvo disposición en contrario.

$\mathrm{X}$. Principio de prioridad excluyente

No puede inscribirse un titulo incompatible con otro ya inscrito o pendiente de inscripción, aunque sea de igual o anterior fecha". 
intrínsecos como extrínsecos. Siendo positivo el resultado de dicha calificación, se procede a extender el asiento de inscripción. Aquí actúan los principios de legalidad ${ }^{38}$ y tracto sucesivo ${ }^{39}$.

- Finalmente, y luego de extendido el asiento de inscripción, actúan los principios de publicidad (formal y material) ${ }^{40}$ y legitimación ${ }^{41}$.

La publicidad es el presupuesto y, en muchos casos, la finalidad de la actuación de los principios registrales; de ello que estemos convencidos de que es el eje del resto de principios registrales, y muchos de estos tienen como finalidad asegurar que se publicite la realidad. Sin publicidad registral, los principios registrales carecerían de contenido y se volverían inútiles en la práctica (y hasta en la sugerente teoría). Reconocer el rol de la publicidad registral es entender la misma esencia del registro jurídico: dotar de notoriedad los actos o derechos que se inscriben; importante presupuesto para la celebración (sobre la base de una garantía conocida como seguridad jurídica) de otros actos o

38 "V. Principio de legalidad

Los registradores califican la legalidad del título en cuya virtud se solicita la inscripción.

La calificación comprende la verificación del cumplimiento de las formalidades propias del título y la capacidad de los otorgantes, asi como la validez del acto que, contenido en aquel, constituye la causa directa e inmediata de la inscripción.

La calificación comprende también la verificación de los obstáculos que pudieran emanar de las partidas registrales y la condición de inscribible del acto o derecho. Se realiza sobre la base del título presentado, de la partida o partidas vinculadas directamente a aquel y, complementariamente, de los antecedentes que obran en el Registro".

39 "VI. Principio de tracto sucesivo

Ninguna inscripción, salvo la primera, se extiende sin que esté inscrito o se inscriba el derecho de donde emana o el acto previo necesario o adecuado para su extensión, salvo disposición en contrario".

40 "I. Publicidad material

El Registro otorga publicidad jurídica a los diversos actos o derechos inscritos. El concepto de inscripción comprende también a las anotaciones preventivas, salvo que este Reglamento expresamente las diferencie.

El contenido de las partidas registrales afecta a los terceros aun cuando estos no hubieran tenido conocimiento efectivo del mismo.

II. Publicidad formal

El Registro es público. La publicidad registral formal garantiza que toda persona acceda al conocimiento efectivo del contenido de las partidas registrales y, en general, obtenga información del archivo Registral [...]".

41 "VII. Principio de legitimación

Los asientos registrales se presumen exactos y válidos. Producen todos sus efectos y legitiman al titular Registral para actuar conforme a ellos, mientras no se rectifiquen en los términos establecidos en este Reglamento o se declare judicialmente su invalidez". derechos. La publicidad registral apunta a la certidumbre, busca la perfección, la perfecta correlación entre lo registrado y la realidad, dado que, al conseguirlo, concede a la sociedad seguridad jurídica. Su impacto no solo se ve en el aspecto jurídico, en el que su rol básicamente es reforzar la buena fe y preservar la eficacia de los actos o negocios jurídicos; su impacto también se extiende a lo social, a lo económico, a lo político y a todo otro campo de las ciencias sociales, dado que el registro responde a una necesidad social: la necesidad de seguridad jurídica. En ello también radica la importancia del principio de titulación auténtica, ya que su nivel de exigencia formal será proporcional a los indices de fraude inmobiliario. La razón es sencilla: el derecho sirve a la realidad y no viceversa.

Por ello, el requisito del documento auténtico para la inscripción se justifica en que proporciona certeza sobre la existencia del acto y la identidad de quienes lo celebran, así como en su matricidad y en el hecho de ser confeccionado bajo reglas rigurosas. Esto quiere decir que por regla serán documentos públicos, ya que «se considera insuficiente que los documentos que contengan los derechos inscribibles estén solamente suscritos por los interesados; se precisa que en su creación haya intervenido una persona dotada por el Estado de facultades legales para conferirles carácter de públicos y auténticos» (Manzano, 1991, p. 440).

En nuestro país se conoce como título, conforme al artículo 7. ${ }^{\circ}$ del TUO del Reglamento General de los Registros Públicos, al «documento o documentos en que se fundamenta inmediata y directamente el derecho o acto inscribible y que, por sí solos, acrediten fehaciente e indubitablemente su existencia [...]». No obstante, la doctrina española diferencia entre título y titulación, entendiendo por título al acto originador del Derecho y por titulación al carácter de la documentación.

Al respecto, Antonio Manzano Solano (1991), citando a Ramón Roca-Sastre, se refiere a las clases de titulación de la siguiente manera: «a) Titulación Ordinaria u originaria. [...] aquella que constituye prueba o documentación directa de un acto o negocio jurídico inscribible. [...] 
b) Titulación Supletoria. Justifica, en cambio, una titularidad del dominio o derecho real, pero no la causa jurídica de su adquisición. Es decir, una prueba indirecta de la adquisición $[\ldots] \gg($ p. 445).

Por otro lado, otra forma en que se garantiza la publicidad que otorga el registro es por medio de la calificación registral, que constituye un filtro legal que efectúa el registrador sobre los títulos que pretenden acceder al registro. Dicha calificación puede tener como resultado (i) la inscripción (si se encuentra conforme); (ii) la observación (defectos subsanables); (iii) la liquidación (faltan pagar derechos registrales); y (iv) la tacha (defectos insubsanables).

Así, a través de una calificación rigurosa, el registrador determina los actos y/o derechos que se inscriben y los que no. En palabras de Antonio Pau Pedrón (1995), «la calificación es un presupuesto lógico a la eficacia del Registro. La intensa eficacia del Registro solo puede producirse por una previa calificación rigurosa» (p. 66). Por ello, si bien el primer requisito es el documento auténtico y con ello tenemos cierto nivel de certeza respecto a la verosimilitud del derecho, será el resultado de la calificación registral el que decida su inscripción, la misma que nace del principio de legalidad y en su aplicación considera otros principios, como el tracto sucesivo.

El resultado esperado de la calificación es que se inscriba el título y que este goce de la protección que otorga el registro. Esta se actúa por medio de una serie de principios como la prioridad (excluyente y preferente), la legitimación registral y la fe pública registral. Para efectos del presente trabajo, centraremos nuestra atención en la legitimación registral en estas líneas y en la fe pública registral más adelante.

La edición original de nuestro Código Civil no contiene sumillas; sin embargo, la reciente modificación del artículo 2013. ${ }^{\circ}$ del Código Civil, por la Ley N. ${ }^{\circ} 30313^{42}$, además de modificar su texto, ha añadido sumillas al citado artículo. Sin perjuicio de ello, este

42 "Artículo 2013.․ Principio de legitimación. El contenido de la inscripción se presume cierto y produce todos sus efectos, mientras que no se rectifique por las instancias registrales o se declare su invalidez por el órgano judicial o arbitral mediante resolución o laudo firme.

[...] La inscripción no convalida los actos que sean nulos o anulables con arreglo a las disposiciones vigentes". artículo había regulado lo que en doctrina se conocía como principio de legitimación registral. Incluso, así fue establecido por Jack Bigio (1990) en la Exposición de Motivos Oficial de nuestro Código Civil, quien se refirió al artículo $2013 .^{\circ}$ del CC de la siguiente manera:

Se puede decir que, teórica y en nuestro caso también legislativamente, existe un doble aspecto de la presunción de exactitud de lo que el registro informa, con la realidad.

Uno de estos aspectos se expresa por medio del principio de legitimidad, o legitimación, como también se le conoce y que admite prueba en contrario; el otro aspecto es el que se expresa mediante el principio de fe pública registral y no admite prueba en contrario.

Es del principio de legitimidad del que nos informa este artículo $[\ldots]$ ( $p .10)$ (resaltado agregado).

Sobre el objeto del principio de legitimación registral, vemos que el artículo $2013 .^{\circ}$ hace referencia al contenido de la inscripción, mientras que el artículo VII del título preliminar del TUO del Reglamento General de los Registros Públicos ${ }^{43}$ hace referencia a los asientos registrales. A esto se añade incluso la terminología de asientos de inscripción que usa el artículo $6 .^{\circ}$ del TUO del Reglamento General de los Registros Públicos ${ }^{44}$. Pero ¿son lo mismo?

Veamos: cada asiento registral implica previamente un acto de inscripción en el derecho administrativo ubicado dentro de los actos administrativos de conocimiento (Morón, 2003, p. 139). En ese sentido, la inscripción registral (acto administrativo final) es un momento del procedimiento registral (su conclusión ${ }^{45}$ ) que se materializa en la elaboración del asiento registral o asiento de inscripción.

43 VII. Los asientos registrales se presumen exactos y válidos. Producen todos sus efectos y legitiman al titular Registral para actuar conforme a ellos, mientras no se rectifiquen en los términos establecidos en este Reglamento o se declare judicialmente su invalidez.

44 Artículo 6. . . Partida Registral

La partida registral es la unidad de registro conformada por los asientos de inscripción organizados sobre la base de la determinación del bien o de la persona susceptible de inscripción [...].

45 Literal a) del artículo 2. ${ }^{\circ}$ del TUO del Reglamento General de los Registros Públicos, aprobado por Resolución N. 126-2012-SUNARP-SN. 
Si lo que genera el acto de inscripción es en sí un asiento, lo que se presume cierto, exacto y válido es el contenido del asiento, mas no el asiento per se ni el contenido de la inscripción (que como ya se dijo es un momento del procedimiento registral). En este caso, se trata de la información (descripción) sobre el acto o derecho inscrito el objeto de dicha presunción iuris tantum.

Esta presunción de certeza, exactitud y validez ocurre como consecuencia de la garantía consagrada en el literal b) del artículo $3 .^{\circ}$ de la Ley $\mathrm{N} .^{\circ} 26366$, esto es, la intangibilidad del contenido de los asientos registrales (la información). Es decir, solo lo plasmado en el asiento, ya sea que se trate de uno de transcripción (literal) o de inscripción (resumen) es intangible, y sobre la base de ello es que se presume cierto, exacto y válido. Al ignorarlo, no se le estaría permitiendo al sistema registral cumplir sus fines. Por lo tanto, el derecho inscrito y su contenido determinado, delimitado y definido por el acto o contrato (título formal) inscrito es lo que propiamente se presume exacto, válido y cierto.

Hasta aquí, tenemos como regla que el asiento es intangible. Como excepción, tenemos que ello se presumirá solo hasta que se inscriba un título modificatorio de la situación jurídica inscrita, judicialmente se declare su invalidez o se rectifique el error contenido en el asiento (error material o de concepto).

Comentando ello, Westermann, H. (2007) $\mathrm{y}$ otros autores alemanes se refieren a los alcances de la presunción de la exactitud del registro en los siguientes términos:

Se presume la existencia del derecho inscrito [...]. Se presume la existencia del derecho con el alcance que le proporciona el Registro como contenido del derecho. La inscripción por sí sola equivale al contenido de los documentos admisibles referidos [...]. La cancelación fundamenta una presunción de que el derecho no existe [...]. (p. 942)

Es necesario precisar que dicha presunción (que se erige como protección de lo inscrito) no ocurre por antojo del legislador. Aquí la función de la aplicación del resto de principios registrales debe propender dicho desarrollo armónico. Para ello, como ya se dijo anteriormente, solo acceden al registro documentos públicos ${ }^{46}$, es decir, los que emanan de autoridades investidas con fe pública.

En el derecho brasileño, Pontes de Miranda (1955) distingue entre fé pública y la eficácia por presunção de autenticidade e verdade al señalar que:

Presunção é menos do que fé pública. A presunção, só por si, não protege o terceiro, porque a presunção se elimina, cancelando-se o registro, ou modificandose, em virtude da retificação. A fé pública assegura a todos que a aquisição ou o modo de proceder, que se baseia na fé pública que o funcionário tenha, está plenamente protegida. (p. 234) ${ }^{47}$

\section{Apariencia jurídica y protección de terceros en el Derecho Civil peruano}

A lo largo del articulado de nuestro CC, pueden apreciarse distintos hechos jurídicos hipotéticos que involucran a los terceros y se erigen como normas de protección de sus derechos. Para hacer una síntesis, el ordenamiento jurídico es uniforme al considerar que el tercero que tenga buena fe es digno de ser tutelado en sus derechos cuando causas ajenas a su conocimiento lo pudieran afectar.

En tal punto es que llegamos al concepto de la apariencia jurídica y sus diferentes contornos. Por ejemplo, en el derecho brasileño, sobre la propiedade aparente se señala que «[...] o direito deve dirigir os seus holofotes para a proteção daqueles que adquirem patrimônio com base em uma titularidade e legitimação para dispor aparentes, mesmo que isso represente o sacrifício econômico do verdadeiro titular» ${ }^{48}$ (Rosenvald, 2006, p. 306).

46 "Solo pueden acceder al Registro títulos válidos, y para ello se exige como regla general - no exenta de excepcionesla necesidad de forma pública, y siempre un control de legalidad por parte del registrador de los títulos que pretenden obtener publicidad registral». (Gómez, 1996, p. 43)

47 Traducción libre: Presunción es menos que fe pública. La presunción, por sí sola, no protege al tercero, porque la presunción se elimina, cancelándose el registro, o modificándose, en virtud de la rectificación. La fe pública asegura a todos que la adquisición o el modo de proceder, que se basa en la fe pública que el funcionario tenga, está plenamente protegida.

48 Traducción libre: [...] el derecho debe dirigir su centro de atención a la protección de aquellos que adquieran patrimonio en base a una titularidad y legitimación para disponer aparentes, aunque eso represente el sacrificio económico del verdadero titular. 
Luego fija que «o princípio básico dos direitos reais é a proteção da aparência ${ }^{49}$ (p. 307) pues «a propriedade estar indissoluvelmente, ligada à sua prova, consubstanciada em investigação da titularidade formal» ${ }^{50}$ (p. 307).

De todo esto, tenemos que, frente a la inexactitud de la situación jurídica aparente, es posible proteger al tercero que actuó de buena fe y confió en dicha apariencia. En el propio derecho brasileño, ello se justifica de la siguiente manera: "Razões sociais e económicas justificam o reconhecimento da eficácia de atos praticados por pessoa que se apresente como proprietária de um bem sem que o seja de verdade, por aparentar a titularidade do direito subjetivo ${ }^{51}$ (p. 307).

En el derecho italiano, el profesor Ángelo Falzea (2006) informa sobre la formación del principio jurídico de la apariencia a partir de la segunda mitad del siglo xIx. Fue Alemania el lugar de vanguardia de esta corriente innovadora, donde su elaboración condujo a la obtención de una coherente y sistemática formulación de la teoría de la apariencia (p. 177). Su justificación se encuentra en «la exigencia de hacer más ágiles las distintas formas de circulación jurídica de los bienes, ocasionada por la expansión del comercio y de los tráficos [...]» (p. 177). Por ello, incluso antes de la elaboración del principio de la apariencia, por la doctrina alemana «los ordenamientos jurídicos de los diversos países iban creando, a través de reiteradas medidas legislativas, excepciones cada vez más numerosas a las reglas tradicionales» (p. 177).

A pesar de la validez de su justificación, el mismo autor nos informa que la recepción de esta construcción teórica por la doctrina italiana y francesa tuvo inicialmente cierta resistencia. Por lo menos en el derecho italiano, y tras intentos de adaptación a partir de la existencia de las teorías de la protección de la expectativa (Venezian) y de la posesión de los derechos (Finzi), puede afirmarse que hoy en día «la idea de la apariencia, a pesar de

49 Traducción libre: El principio básico de los derechos reales es la protección de la apariencia.

50 Traducción libre: La propiedad está indisolublemente ligada a su prueba, basada en la investigación de la titularidad formal.

51 Traducción libre: Razones sociales y económicas justifican el reconocimiento de la eficacia de los actos practicados por la persona que se presente como propietaria de un bien sin que lo sea de verdad, por aparentar la titularidad del derecho subjetivo. incertidumbres y escepticismos, es reconocida con carácter general por la doctrina italiana» (Falzea, 2006, p. 180).

Debo enfatizar en la vinculación entre la apariencia y el principio general de publicidad (Publizitätsprinzip), cuyo supuesto identifica que «el acto realizado por el tercero con un sujeto que no tiene la titularidad del derecho es eficaz [...] como si se hubiese realizado con el titular, siempre que un título de investidura formal de aquel sujeto cree una situación de confianza del tercero» (ibid., p. 181). Es decir, se protegerá al tercero siempre y cuando su confianza se justifique en un título formal del cual surge la apariencia del derecho. Por ello, se considera ligada la figura de la apariencia con el formalismo; no solo eso, sino que el propio formalismo constituye un medio de protección de la buena fe de los terceros (ibid., 2006, p. 191). Falzea (2006) nos da una interesante precisión:

\section{La apariencia no es un aparecimiento opaco, un puro hecho que únicamente se revela a sí mismo, porque un fenómeno que se limita a revelarse a sí mismo jamás puede ser aparente. Este fenómeno se presenta como aquello que es; la apariencia, por el contrario, surge solo cuando un fenómeno hace que otro fenómeno, además de sí mismo, aparezca, $y$ lo hace aparecer como real, aunque es irreal. (p. 183) (Resaltado agregado).}

Teniendo clara su formación y su aplicación más usual en cuanto al derecho de propiedad en la dinámica del derecho comparado, es necesario hacer un breve recorrido en nuestro Derecho civil y su vinculación con la protección de terceros.

Desde nuestro primer Código Civil (1852), se reconocía en su articulado diversas aplicaciones de la protección de la apariencia en cuanto a los terceros. Así, se reconocen distintas hipótesis, como la protección del tercero que hubiera contratado de buena fe con los esposos cuyo matrimonio hubiera sido declarado nulo (art. 172..$^{\circ}$ ); del tercero que hubiera contratado con los cónyuges cuando ejercían independientemente sus derechos civiles y se produjera la cesación del divorcio (art. 271. ${ }^{\circ}$ ); del tercero que hubiera comprado del primer adquiriente en la rescisión de la venta de cosas muebles ya entregadas con precio no afianzado ni pagado (art. 1392..$^{\circ}$ ); del tercero 
no notificado con la revocación del mandatario (art. 1945. ${ }^{\circ}$ ); del tercero que adquirió derechos del deudor y este quiera dar su crédito en compensación (art. 2263..$^{\circ}$ ); y, del tercero que adquirió derechos de una de las partes y estas quieran extinguir sus obligaciones por mutuo disenso (art. 2272. ${ }^{\circ}$ ).

Posteriormente, en nuestro Código Civil de 1936 se reconocen las hipótesis de protección del tercero que adquiere, a título oneroso, bienes de los herederos poseedores en el escenario de reivindicación de la herencia (art. 664. ${ }^{\circ}$ ); del tercero que haya adquirido derechos luego de la partición, cuando esta luego se rescinda (art. 798. ${ }^{\circ}$ ); del tercero que hubiera contratado a título oneroso con el mandatario con poder revocado no inscrito (art. 1068. ${ }^{\circ}$ ); del tercero a título oneroso y de buena fe que contrató con la persona favorecida por la simulación de un negocio jurídico (art. 1097..$^{\circ}$ ); del tercero en la confirmación del acto anulable (art. 1132. ${ }^{\circ}$ ); del tercero en el mutuo disenso (art. 1317. ${ }^{\circ}$ ); del tercero de buena fe con el primer comprador en la rescisión de la venta de cosas muebles ya entregadas con precio no pagado ni afianzado (art. 1416. ${ }^{\circ}$ ); del tercero adquiriente de un bien a título oneroso que hubiera sido donado (art. $\left.1478 .^{\circ}\right)$; del tercero por el ejercicio ultra vires del mandatario (art. 1646. ${ }^{\circ}$ ); del tercero de buena fe que hubiera adquirido derechos por los actos efectuados por el liquidador de una sociedad (art. 1741..$^{\circ}$ ); y el tercero de buena fe en la nulidad del contrato de deudas de juego (art. $1769 .^{\circ}$ ).

Finalmente, en nuestro Código Civil vigente (1984) se regulan las hipótesis de protección del tercero que hubiera contratado con el representante cuando su revocación no conste inscrita (art. 152. ${ }^{\circ}$ ); del tercero que hubiera contratado con un representante que excedió sus facultades (art. 162..$^{\circ}$ ); del tercero de buena fe y a título oneroso que hubiera adquirido derechos del titular aparente en la simulación (art. 194. ${ }^{\circ}$ ); del tercero subadquiriente de buena fe en la declaración de ineficacia del negocio jurídico previo (art. 197. ${ }^{\circ}$ ); del tercero de buena fe en el matrimonio invalidado (art. 285. ${ }^{\circ}$ ); del tercero frente al fenecimiento del régimen de sociedad de gananciales no inscrito (art. 319. ${ }^{\circ}$ ); del tercero que de buena fe y a título oneroso hubiera adquirido bienes hereditarios del heredero aparente (art. 665..$^{\circ}$ ); del tercero frente a un pacto de indivisión no inscrito (art. 848..$^{\circ}$ ); del tercero adquiriente de buena fe y a título oneroso en la nulidad de la partición con preterición de algún sucesor (art. 865..$^{\circ}$ ); del tercero a título de oneroso y de buena fe en el pago indebido (art. $1270 .^{\circ}$ ); del tercero en la condonación (art. 1295..$^{\circ}$ ); del tercero en la consolidación (art. $1301 .^{\circ}$ ); del tercero perjudicado por el mutuo disenso (art. 1313..$^{\circ}$ ); del tercero en cuanto al pacto de reserva de propiedad no inscrito (art. 1584..$^{\circ}$ ); del tercero frente al pacto de retroventa (art. 1591..$^{\circ}$ ); del tercero de buena fe en la nulidad de los actos relacionados a las deudas de juego y apuestas (art. 1945..$^{\circ}$ ); del tercero en la fe pública registral (art. 2014. ${ }^{\circ}$ ); del tercero que celebre contratos onerosos y de buena fe en el lugar donde debieron inscribirse los actos relacionados al registro personal (art. 2034. ${ }^{\circ}$ ); y el tercero de buena fe y a título oneroso sobre la base de un mandato o poder inscrito frente a la modificación o extinción no inscritas (art. 2038. ${ }^{\circ}$ ).

Aunque en los inicios de la codificación civil en nuestro país se reconocía tímidamente la protección de los terceros sobre la base de la confianza depositada en la apariencia jurídica, al día de hoy se vincula dicha protección incluso con la publicidad. En nuestro sistema existen dos formas de publicidad de los derechos: la posesión $^{52}$ y la publicidad del registro. En este sentido, diferimos de Francisco Hernández Gil, quien opina que «la tutela de la apariencia tiene su máximo desarrollo justamente donde falta un sistema de publicidad adecuado. La apariencia puede ser un medio complementario de la publicidad, cuando ella no existe o resulta defectuosa, pero la publicidad lo que procura es hacer conocer "realidades", no apariencias" (Hernández, 1963, p. 14). Como bien hemos visto, la apariencia jurídica surge de los hechos jurídicos y su tutela dependerá de que se cumplan los requisitos que exija la norma. De nuestra revisión, hemos advertido que generalmente se exigen la buena y la adquisición a título oneroso, tanto en la protección de la confianza del tercero como en la buena fe respecto a la situación jurídica aparente.

52 Criticando la posesión como medio económicamente eficiente de publicidad: "Está bien que se obtenga la propiedad mediante la posesión cuando la propiedad no es de nadie, nadie la reclama y no hay título alguno sobre ella, pero una vez que es adquirida mediante esa forma, debe ser suficiente para mantenerla y poder registrar el título para alejar a cualquier entrometido. Este es un método más barato de dar publicidad, que elaborar señales y cercar la propiedad, dejando de lado los mecanismos que se utilizan en el presente, como método requerido para obtener el título de la terra incógnita. Este es otro ejemplo de por qué un sistema de derechos posesorios puro es antieconómico" (Posner, 2011, p. 66). 


\section{Fe pública registral ${ }^{53}$}

En nuestro Código Civil se reconoce en el artículo $2014 .^{\circ}$ el principio de fe pública registral, conforme a su exposición de motivos (Bigio, 1990, p. 11). Su antecedente inmediato responde al art. $1052 .^{\circ}$ del Código Civil de 1936, inspirado a su vez en el artículo 34 de la Ley Hipotecaria española (LHE) de 1946, el que a su vez se basó en el artículo 973. ${ }^{\circ}$ del Código Civil suizo (Gordillo, 2010, p. 18), según un sector de la doctrina española. Esta se refiere a la fe pública registral contenida en el artículo $34 .^{\circ}$ de su LHE, en el sentido de que «favorece la seguridad del tráfico inmobiliario, y lo hace asegurando las expectativas del tercero que confía en una apariencia jurídica que merece protección. Lo habitual es que la fe pública purifique una inexactitud en la titularidad dominical de la finca registral [...]» (Arrieta, 2009, p. 189).

Dado que la exposición de motivos del artículo 2014. ${ }^{\circ}$ de nuestro Código Civil reconoció expresamente como su formante legislativo al artículo $34 .^{\circ}$ de la LHE — y habiendo indagado brevemente en la opinión de su doctrina sobre el particular-, podemos remitirnos al texto del art. 2014. ${ }^{\circ}$ del $\mathrm{CC}$, recientemente

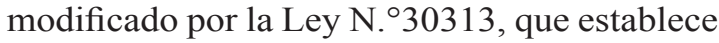
lo siguiente:

\section{El tercero que de buena fe adquiere a título oneroso algún derecho de persona que en el registro aparece con facultades para otorgarlo, mantiene su adquisición una vez inscrito su derecho, aunque después se anule, rescinda, cancele o resuelva el del otorgante por virtud de causas que no consten en los asientos registrales y los títulos archivados que lo sustentan.}

La buena fe del tercero se presume mientras no se pruebe que conocía la inexactitud del registro.

A su vez, dicha disposición es redactada en clave más técnica-registral a través del artículo VIII del Título Preliminar del TUO del Reglamento General de los Registros Públicos, bajo el siguiente tenor:

53 El contenido de este ítem constituye una versión integramente revisada de la sección que dediqué a la fe pública registral en mi tesis para obtener el titulo profesional de abogado, intitulada "Protección registral y nulidad de oficio del título de concesión minera". Recuperado de http://www.repositorioacademico.usmp. edu.pe/bitstream/usmp/1439/1/escajadillo_cfj.pdf Consultada el 28/03/2016.
La inexactitud de los asientos registrales por nulidad, anulación, resolución o rescisión del acto que los origina no perjudicará al tercero registral que a título oneroso y de buena fe hubiere contratado sobre la base de aquellos, siempre que las causas de dicha inexactitud no consten en los asientos registrales.

Como puede apreciarse, la parte pertinente a los asientos registrales de la norma citada en el párrafo que antecede ha quedado sin efecto a partir de la entrada en vigencia de la Ley 30313 . $^{\circ}$ dado que, en la actualidad, es necesario que para calificar la buena fe del adquiriente, la inexactitud no conste en los títulos archivados.

A diferencia del art. $2014 .^{\circ}$ del CC, la norma reglamentaria se refiere a que la inexactitud registral por causas que originen la extinción del título material no va a perjudicar al tercero registral. Para ello, el artículo $2014 .^{\circ}$ es el que establece los requisitos que este tercero debe cumplir para ser considerado un tercero registral (Soria, 2012, p. 75). Naturalmente, dicha inexactitud no debe constar ni en el asiento registral ni en el título archivado, dado que, aplicando el principio de publicidad, ello sería cognoscible y ergo no puede alegarse la buena fe, como ya se ha mencionado.

En este supuesto, debemos distinguir entre dos tipos de nulidades presentes en el asiento de inscripción: la nulidad del título (material o formal) que sustenta la existencia del asiento; y la nulidad del asiento per se, debido a que la rectificación de la inexactitud no es posible por no tratarse de un error material o de concepto. El primero deja sin efecto la inscripción, cuya consecuencia inmediata es la cancelación (Soria, 2012, p. 170), mientras que el segundo cancela propiamente la inscripción (ibid., 2012, p. 171).

La protección registral no es más que la actuación conjunta de los principios que determinado sistema registral despliega sobre los actos inscritos. Para ello, la información que el registro administra está garantizada antes de la inscripción.

El principio de fe pública registral está estrechamente vinculado con el de legitimación registral (García, 1993, p. 227). De ello, afirmamos que el elemento central de la protección desplegada por la fe pública 
registral se basa en la confianza en el registro, siendo de ello lo que deriva gran parte de la construcción de la buena fe del adquiriente.

Un análisis interesante hecho ya hace muchos años sobre el artículo $2014 .{ }^{\circ}$ del CC es que «resulta claro que se trata de normas que [...] no tienen como finalidad constituir derechos, sino otorgar protección a terceros que [...] cumplen con los requisitos para merecer tal protección» (Del Solar, 1994, p. 169).

Hecho el recuento de sus fundamentos y naturaleza, solo queda delimitar los requisitos de su aplicación. Para ello, transcribimos lo señalado en la Casación N. ${ }^{\circ}$ 1812-2010 AYACUCHO:

Tercero. [...] Para la aplicación del citado principio de fe pública registral es menester que concurran los requisitos siguientes: a) Debe tratarse de una adquisición derivada de un titular registral [...]; b) Debe existir una inexactitud registral no conocible por el tercero adquiriente que afecta el derecho del titular registral transferente por causales de invalidez, ineficacia o falsedad; c) El adquiriente debe tener título válido y ser tercero respecto de las relaciones jurídicas anteriores afectadas [...]; d) La adquisición por el tercero debe ser de buena fe y a título oneroso; y e) El acto adquisitivo del tercero debe estar inscrito.

\section{ANÁLISIS Y DISCUSIÓN}

\section{Fe pública registral vs. Derecho de propiedad: ¿Qué se ha hecho?}

Habiendo abarcado diversos temas vinculados al derecho de propiedad y la fe pública registral, es preciso abarcar el problema a partir de un primer análisis desde nuestra doctrina nacional. Gunther Gonzáles Barrón (2015) critica la protección de la fe pública registral para el fraude inmobiliario a partir de los siguientes argumentos: (i) Solo se adquiere la propiedad por medio de un título legítimo, reconociendo dentro de ellos la compra, la herencia o la posesión (pp. 33-50); (ii) solo se adquiere la propiedad por hechos y no por los no-hechos (nada); esto es consecuencia de lo anterior, y señala que es un imposible lógico que la causa de la propiedad sea un nohecho como lo es un título falso (pp. 51-65); (iii) la fe registral es una regla de aplicación excepcional (pp. 67-79); (iv) la fe registral no ampara falsificaciones, ya que el derecho de propiedad es inviolable (pp. 135-152); y (v) ni la calificación registral ni la inscripción pueden modificar la realidad (pp. 153-167).

Por su parte, Rómulo Morales Hervias (2011), quien entiende que el principio de fe pública registral es una excepción a la falta del poder de disposición (p. 387), se opone básicamente a la construcción de la buena fe del adquiriente. Para ello señala que no solo puede basarse en el registro, sino también en la posesión, ya que la buena fe del tercer adquiriente no puede pesar más que la realidad misma (p. 385). Además, este autor señala que no se protege al tercero si es que la demanda de nulidad o inoponibilidad se inscribe dentro del plazo de su prescripción (p. 407).

De otro lado, Gilberto Mendoza del Maestro (2013) define que la legitimación que deriva de la propiedad aparente goza de juridicidad (p. 8) y señala que es mucho más que legitimación aparente, ya que es un supuesto de hecho complejo que incluye la buena fe del adquiriente (p. 52). Con ello niega la aplicación de la fe pública registral al supuesto de nulidad por ausencia de manifestación de voluntad por no existir un título de adquisición del otorgante emitido por el verdadero propietario (p. 52). El autor sustenta esto al considerar que, aplicando analógicamente el art. $948 .^{\circ}$ del CC, se ausenta un requisito que debe tener el propietario aparente, es decir, haber obtenido mediante un título la posición externa de propietario, quedando fuera las falsificaciones de este supuesto de adquisición a non domino, ya que no existe voluntad de declaración (p. 51).

Para Martín Mejorada Chauca (2015), ambos son derechos de propiedad, tanto el tercero inocente como el titular afectado; sin embargo, opina que la opción no pasa por preferir un derecho por ser mejor que el otro, sino por proteger al que mejor aporta a la sociedad. De ello que se incline por la protección del inscrito, ya que se cumplen los objetivos de la propiedad como figura económica. Por ello, considera que el problema no se resuelve eliminando o restringiendo la fe pública registral, sino controlando mejor el proceso de inscripción e impidiendo el acceso de títulos irregulares (p. 237). De otro modo, Guillermo Sierra Vásquez (2011) señala que no siempre se requiere la concurrencia de la manifestación 
de voluntad del titular del derecho para la circulación jurídica de bienes, poniendo el caso de la adquisición a non domino (p. 162).

Vemos que no existe consenso sobre qué debemos proteger a nivel doctrinario, si bien debe primar la protección del derecho del tercero registral o del propietario perjudicado. A nivel normativo, el 26 de marzo de 2015 se publicó en el diario oficial El Peruano la Ley de oposición al procedimiento de inscripción registral en trámite y cancelación del asiento registral por suplantación de identidad o falsificación de documentación y modificatoria de los artículos $2013 .^{\circ}$ y $2014 .^{\circ}$ del Código Civil y de los artículos $4 .^{\circ}$ y $55 .^{\circ}$ y la quinta y sexta disposiciones complementarias transitorias y finales del Decreto Legislativo N. ${ }^{\circ} 1049$ (Ley N. ${ }^{\circ}$ 30313). La formación de esta, como es notorio, responde al problema de la falsificación de documentos y la suplantación de identidades, introduciendo distintas modificaciones en nuestro sistema registral-notarial peruano.

La primera de ellas constituye una excepción a la regla general contenida en el artículo $1 .^{\circ}$ del TUO del Reglamento General de los Registros Públicos. Ello ya que el procedimiento registral, al ser de naturaleza no contenciosa, no admitía oposición al trámite con la actual modificación; se establecen supuestos de legitimación restringida para plantear la oposición siendo los notarios, jueces, funcionarios públicos, cónsules y presidentes de tribunales arbitrales los únicos legitimados para tal fin. La segunda hace alusión a la competencia del jefe zonal para resolver las solicitudes de cancelación formuladas por los sujetos legitimados ya mencionados. Esto no constituye una declaración de invalidez del negocio causal, sino que, por dicha declaración, cesan los efectos erga omnes que este producía como consecuencia de su acceso al registro.

Tanto la oposición como la cancelación giran en torno a dos supuestos de hecho específicos: (i) la suplantación de la identidad de los otorgantes y (ii) la falsificación del título formal. Dada su naturaleza de acuerdo inter partes, solo el primero de ellos puede ser comunicado mediante una declaración del notario o el cónsul. En tanto, el segundo supuesto es susceptible de ser comunicado por las autoridades antes mencionadas.
Si bien respecto a la oposición al procedimiento registral no encuentro mayor inconveniente, respecto a la cancelación siempre se deja la puerta abierta para que se siga produciendo el «efecto perverso» en la aplicación del principio de fe pública registral. A pesar de que se haya modificado el artículo 2014. ${ }^{\circ}$ del CC y se haya añadido que el estándar de buena fe del adquiriente implica que este desconozca la patología del título formal y material tras su verificación tanto de los asientos registrales como de los títulos archivados, los efectos de la cancelación no perjudicarán al tercero del artículo $2014 .^{\circ}$ del CC. Es decir, para mantener la adquisición (ya sea porque el título formal sea espurio o porque el material sea írrito) el nivel de diligencia exigible es verificar la información de los títulos archivados, y si de ella se advierte que se pudo conocer la suplantación de identidad o la falsificación del documento, no se tiene buena fe, por lo que se pierde lo adquirido.

No obstante, se presenta un gran problema resumido en una pregunta sencilla: $\mathrm{Si}$ el registrador como especialista no pudo advertir la suplantación de identidad o la falsificación del documento al efectuar la calificación registral, ¿cómo lo haría un particular? ¿Acaso la norma sugiere el hecho que mi calificación es superior a la del registrador? Ello no es más que absurdo. Así, el adquiriente podrá argumentarlo con toda justificación. Nos encontramos en el supuesto de que el registrador no está coludido con la mafia inmobiliaria, porque si lo estuviera y el título es claramente falso, el tercero no podrá alegar tener buena fe.

Otra modificación que encuentro cuestionable es respecto a la competencia territorial del notario para dar fe de los negocios jurídicos, sancionando con nulidad de pleno derecho los celebrados fuera del ámbito de su competencia territorial (sea provincial o distrital).

Las disposiciones de esta ley, junto al bloqueo por presunta falsificación de documentos (Directiva N. ${ }^{\circ} \quad 001-2012-S U N A R P / S N$ ), la tacha por falsedad documentaria (art. 36. ${ }^{\circ}$ del TUO del Reglamento General de los Registros Públicos), alerta registral (Directiva N. ${ }^{\circ}$ 006-2013-SUNARP/SN) y la inmovilización temporal de partidas (Directiva N. ${ }^{\circ}$ 08-2013-SUNARP/SN) son respuestas que se han dado a este gran problema. Lamentablemente, estamos convencidos de que no cumplen la finalidad propuesta, ya que solamente son parches. 
En cuanto a los proyectos de ley, a lo largo de estos años se han elaborado varios. Por ejemplo, el Proyecto de Ley N. ${ }^{\circ} 3365 / 2013-$ CR, que modifica el artículo $2014 .^{\circ}$ del CC, pretendiendo introducir en su texto que «la buena fe del tercero se presume, siempre y cuando el propietario originario o el precedente transferente sean notificados previamente al acto traslativo de dominio, por este o por el tercero mediante carta notarial de fecha cierta». Como justificación a semejante propuesta, se argumenta sobre la buena fe del tercero adquiriente que «no permite tener control previo frente a la eventual consumación de un acto ilícito». Es otro el caso del Proyecto de Ley N. ${ }^{\circ} 3848 / 2014-$ CR, cuya propuesta sobre el art. $2014 .^{\circ}$ del $\mathrm{CC}$ busca introducir lo siguiente: «El tercero de buena fe no contará con la protección del registro en los casos en que adquiera un bien dentro de los tres meses de adquirido este por su transferente, hasta los seis meses siguientes de realizada la inscripción».

Por otra parte, tenemos al Proyecto de Ley N. ${ }^{\circ}$ 3029-2013/CR, cuya modificación se centra en añadir que «no resulta aplicable la presunción de buena fé [sic], si se ha transferido un inmueble en dos oportunidades o más en un periodo menor a 1 año».

Por otro lado, el Proyecto de Ley N. ${ }^{\circ}$ 3350/2013-CR buscó añadir un último párrafo al art. $2014 .^{\circ}$ del CC para señalar que:

No se puede invocar la buena fe a que se refiere el párrafo precedente si los actos de disposición previos se realizaron sin que el registrador notifique en la dirección del bien materia de disposición, a la persona que en el registro aparece con facultades para otorgar el derecho y adicionalmente en una segunda dirección que obligatoriamente el titular del derecho comunica, la que puede ser electrónica.

Las notificaciones surten efectos si vencidos siete días útiles de efectuadas, el notificado o su apoderado no formula oposición alguna.

Estos fueron algunos proyectos de ley sobre el tema de la fe pública registral y la falsificación de documentos. No obstante, estamos convencidos de que ni las normas dadas o los proyectos de ley han atacado el quid del problema.

\section{La falsificación de documentos en el Perú: tutela punitiva}

El problema de la falsificación de documentos tiene también incidencia en el Derecho Penal. Verbi gratia, el falsificador de un documento público ingresado a la Sunarp incurre en infracción de lo previsto en el artículo $427 .^{\circ}$ del Código Penal ${ }^{54}$, siendo además considerado como un agravante el hecho de que el documento falso o adulterado sea un documento público, como las escrituras públicas. No obstante, la propia redacción de dicho artículo propone que debe existir algún perjuicio derivado del documento falso o adulterado, como es el caso del propietario que no manifestó su voluntad de transferir y, sin embargo, se falsificó un documento donde ello se constata.

Sobre el tema, la jurisprudencia penal estableció en la RN N. ${ }^{\circ}$ 5407-97-HUAURA que:

La minuta de compra-venta (sic) fraguada por la encausada no tiene el carácter de documento público sino más bien de privado, toda vez que se entiende por documento público a todo aquel que ha sido formalizado según los requisitos legalmente establecidos por un funcionario público que ejerza labor notarial o de fedatario, contrario sensu, se tendrá por documento privado a todo aquel que no se encuentre comprendido en este concepto, como es el caso de las minutas [...]».

Como se sabe, el delito de falsedad documental se enmarca dentro del Título XIX del Código Penal y se ubica como uno de los tipos de delitos contra la fe pública. Respecto al bien jurídico protegido por estos tipos de delitos, José Luis Castillo (2001) advierte que la doctrina suele considerar tanto la fe pública

54 Artículo $427 .^{\circ}$ del Código Penal. El que hace, en todo o en parte, un documento falso o adultera uno verdadero que pueda dar origen a derecho u obligación o servir para probar un hecho, con el propósito de utilizar el documento, será reprimido, si de su uso puede resultar algún perjuicio, con pena privativa de libertad no menor de dos ni mayor de diez años y con treinta a noventa días-multa si se trata de un documento público, registro público, título auténtico o cualquier otro transmisible por endoso o al portador y con pena privativa de libertad no menor de dos ni mayor de cuatro años, y con ciento ochenta a trescientos sesenticinco dias-multa, si se trata de un documento privado.

El que hace uso de un documento falso o falsificado, como si fuese legítimo, siempre que de su uso pueda resultar algún perjuicio, será reprimido, en su caso, con las mismas penas. (Resaltado agregado). 
(p. 18) como la seguridad y fiabilidad del tráfico jurídico (p. 32) o al propio documento y algunas propiedades que son inherentes a él (p. 44). Sin perjuicio de ello, coincidimos con este autor cuando argumenta que:

En los delitos de falsedad documental $y$, en general, en el Derecho penal no se protege ningún bien jurídico de indole moral o ética, a manera de un deber o un derecho a la verdad, sino que en vez de ello se impondría más bien la prohibición de no crear documentos falsos, de no adulterar documentos verdaderos $y$ de no insertar declaraciones falsas, ya que sobre un documento existe la confianza de autenticidad y fiabilidad tanto interpersonal [por parte de los involucrados en la relación jurídica] como de la sociedad en su conjunto (pp.16 y 17).

Siendo un delito doloso (es decir, debe existir consciencia y voluntad del agente), no cabe la imputación por culpa. Evidentemente, una de las muchas razones de los delitos contra el patrimonio reside básicamente en la avaricia de las personas. La riqueza o la pobreza son solo elementos accesorios, ya que lo determinante es el afán desmedido de adquirir bienes valiosos, algo que, además, se corrobora en la realidad con una simple pregunta: ¿Acaso los ricos no roban? Que tal vez sea menos probable no quiere decir que la respuesta sea negativa. Lo mismo ocurre en el delito de falsedad documental en el caso de escrituras públicas con transferencias que el propietario real no ha firmado, pues se trata de un robo, al margen de la denominación que se le dé al tipo de delito.

Por otra parte, la labor de los funcionarios públicos en estos casos responde a un problema de raigambre, digámoslo así, tradicional en nuestra sociedad: la corrupción. En el caso de los registradores públicos, por ejemplo, la sola aceptación de cualquier tipo de ventaja que se le otorgue a fin de que inscriba un documento falsificado o adulterado, se tipifica como cohecho pasivo propio (art. $393 .^{\circ}$ del Código Penal).

Como vemos, las sanciones están previstas. La situación está en fomentar su aplicación y aumentar la capacidad de detección de estos ilícitos a fin de fortalecer su carácter disuasivo.

\section{CONCLUSIONES Y PROPUESTA}

Como hemos visto, la propiedad no es un derecho subjetivo cualquiera; además, es una garantía institucional y el Estado debe garantizar su respeto (inviolabilidad). Solamente garantizando su respeto, el titular del derecho de propiedad podrá ejercer las facultades que el derecho confiere sin interrupción alguna. Si hubiera interrupción, puede recurrir a los mecanismos de protección que el ordenamiento provee.

El esquema de adquisición del derecho de propiedad no es lejano a la adquisición de un derecho cualquiera, es decir, es la norma la que establece el hechojurídico que deberá cumplirse para ligar el efecto jurídico adquisitivo. Así, nuestro ordenamiento jurídico prevé cinco hechos adquisitivos: (i) la apropiación, (ii) la especificación y mezcla, (iii) la accesión, (iv) la transmisión de la propiedad y (v) la prescripción adquisitiva de dominio.

Muchos de los hechos adquisitivos son de formación sucesiva (concurrencia de más de un hecho jurídico) y otros de formación instantánea. Sin embargo, al centrarse nuestro análisis en el hecho adquisitivo más común (la transmisión de la propiedad de bienes inmuebles), es que comprobamos que el hecho adquisitivo es la existencia de la sola obligación de enajenar, es decir, el contrato por el cual se dispone la transferencia del bien (compraventa, permuta o donación). Atendiendo a que no estamos frente a una formalidad ad solemnitatem, cualquier forma de exteriorizar el negocio jurídico de adquisición será válida y permitirá que produzca todos sus efectos.

No debemos ser ajenos al resto de normas de nuestro propio ordenamiento, ya que en los escenarios de conflicto se establece un orden de prelación entre los modos de probar el derecho. Gracias al alto grado de certeza que producen los derechos inscritos es que en la mayoría de casos son preferidos frente a los derechos no inscritos. Así, principios como la fe pública registral son solo normas de protección y no de adquisición o de creación de derechos, dado que tienen su base en la confianza (buena fe) del tercero en la información registral que se presume cierta, exacta y válida (legitimación registral). Asimismo, la fe pública registral es entendida como una excepción al principio nemo plus iuris ad alium tranferre potest quam 
ipse haber. Lo que hemos descrito es coherente con toda la formulación del sistema registral y constituye, básicamente, la función protectora del registro en cuanto al hecho adquisitivo.

Lamentablemente, el conflicto entre preferir al tercero registral del artículo $2014 .^{\circ}$ del CC y al propietario perjudicado con la falsificación encierra un contenido ambivalente. Tanto el propietario perjudicado como el tercero inscrito han adquirido su derecho sobre la base de su confianza en el registro, por lo que, precisamente, también es función de la fe pública registral garantizar la inviolabilidad de la propiedad, otorgándole un grado máximo de protección preferente en cualquier escenario de conflicto. No ocurre lo mismo en el caso de los bienes muebles (no registrables) en los que la posesión es el medio de publicidad más efectivo, ya que si el tercero que de buena fe adquiere un bien mueble perdido o adquirido en infracción de la ley penal no se podrá proteger su adquisición (art. 948. ${ }^{\circ} \mathrm{del} \mathrm{CC}$ ).

En nuestro ordenamiento, la traditio es el modo de transferir la propiedad (art. 947. ${ }^{\circ}$ del CC). Propiamente, es el hecho adquisitivo y la posesión misma es la publicidad del derecho. A pesar de ello, si el bien se ha perdido o se adquiere en infracción de una ley penal, no se protege al tercero, es decir, es una excepción al hecho adquisitivo provisto. No obstante, eso no ha sido previsto para el caso de los bienes inmuebles en donde se precisa de un mecanismo de protección superior a la posesión.

El registro en su actuar ordinario e ideal brinda una legitimación registral. Excepcionalmente, en algunos casos no deseados de inexactitud, brinda una legitimación aparente en la que adquiere relieve el concepto de la apariencia jurídica y la protección que de ella deriva para los terceros de buena fe y a título oneroso, en la gran mayoría de casos. Es decir, negamos la inaplicación del principio de fe pública registral en los casos de fraude inmobiliario, ya que el tercero confía en la apariencia y en nuestro ordenamiento se protege al tercero de buena fe y a título oneroso que contratan confiando en dicha apariencia. Además, no existe norma que establezca expresamente el supuesto de fraude inmobiliario como excepción al principio de fe pública registral.

Aunque la falsificación sea un hecho que todos repudiamos, debemos reconocer que en principio una falsificación no debería acceder al registro. Del mismo modo, una suplantación de identidad no debería darse en una oficina notarial, donde el notario ejerce su función en forma personal (art. 3. ${ }^{\circ}$ del Decreto Legislativo N. ${ }^{\circ} 1049$ ) y se le impone la obligación de requerir a las partes intervinientes su DNI y verificar su identidad (literal d) del artículo $16 .^{\circ}$ del DL N. ${ }^{\circ} 1049$ ).

Aquí, resalta lo infructuoso de las modificaciones, ya que, si bien en el caso de la Ley N. ${ }^{\circ} 30313$ se identificaron claramente los supuestos de hecho fraudulentos (falsificación de documentos o suplantación de identidades), no se tomaron medidas para prevenir su producción. Por ello, lo que se debe fortalecer son los procedimientos para hacerlos más estrictos y modernos. Estamos convencidos de que recurrir a la tecnología ayudará a prevenir estos hechos indeseados y permitirá fortalecer ${ }^{55}$ el sistema de adquisición de bienes.

Estamos convencidos de que un paso importante hacia ello ha sido la implementación del Sistema de Intermediación Digital (SID Sunarp), con la Directiva N. ${ }^{\circ} 004-2014-S U N A R P / S N$, aprobada por Resolución del Superintendente Nacional de los Registros Públicos N. ${ }^{\circ}$ 234-2014-SUNARP/ SN de fecha 17 de septiembre de 2014 y la reciente ampliación del servicio de presentación electrónica del parte notarial digital para el acto de compraventa en el Registro de Predios, aprobado a su vez por la Resolución del Superintendente Nacional de los Registros Públicos $\mathrm{N} .^{\circ}$ 068-2016-SUNARP/SN ${ }^{56}$. Este fue aceptado tímidamente, ya que solo se admitirá siempre y cuando se trate de un solo predio, una sola partida registral, titular-transferente y no se transfieran cuotas ideales. Una adecuada ampliación y difusión de medidas como esta nos ayudará a prevenir el ingreso de documentos públicos falsos al registro, aunado a la responsabilidad del notario que haya realizado el envío electrónico del parte notarial digital a la Sunarp.

Para el caso de suplantación de identidades, nos queda más que recomendar el uso obligatorio del biométrico a nivel nacional, ya que es la única forma de garantizar las identidades de las partes. Podrá falsificarse un DNI, pero jamás una huella digital.

55 "Se trata de una cuestión técnica, y se procuran utilizar los progresos científicos para brindar los soportes más seguros para la conservación de los datos, y la rapidez y facilidad en su consulta, de manera que se haga efectiva la publicidad como forma de proteger la seguridad jurídican Moisset de Espanés, Luis (2004). La publicidad registral, 4. ${ }^{a}$ edición, Lima: Palestra. Pág. 50.

56 Publicada el 14 de marzo de 2016 en el diario oficial El Peruano. 
Estamos convencidos de que, con la correcta implementación de estas medidas, podemos dar solución a los casos de fraude inmobiliario. Esto demuestra que muchas veces las soluciones a los problemas jurídicos no se encuentran solo en la elaboración de complejas teorías o recurriendo al dogmatismo innecesario. En un mundo como el de hoy, es posible recurrir a la tecnología para dar soluciones prácticas y eficaces a grandes problemas jurídicos.

\section{REFERENCIAS BIBLIOGRÁFICAS}

Álvarez Caperochipi, José Antonio (1986). Curso de Derechos Reales, tomo I, Propiedad y Posesión. Madrid: Civitas.

Aparicio y Gómez Sánchez, Germán (1942). Código Civil, concordancias, tomo III, La Reforma (Motivos). Lima: Taller de Linotipia.

Arrieta Sevilla, Luis Javier (2009). «Fe pública registral, doble inmatriculación y usucapión: Comentario a la STSJ Navarra de 28 de abril de 2008 [RAJ 2009/306]». En: Revista Jurídica de Navarra, enero-junio, (47), pp. 183-201. Navarra.

Aubry, Charles y Rau, Charles-Frédéric (1897). Cours de droit civil francais d'après la méthode de zachariae, 15. ${ }^{a}$ edición. París: Marchal et Billard.

Avendaño Váldez, Jorge (1980). «De los Derechos Reales. Anteproyecto del Dr. Jorge Avendaño Váldez». En: Proyectos y Anteproyectos de la Reforma del Código Civil. Lima: Fondo Editorial de la Pontificia Universidad Católica del Perú. Pp. 763-808.

Barbero, Doménico (1967). Sistema del Derecho Privado, tomo I, Introducción Parte Preliminar - Parte General, Traducción de Santiago Sentis Melendo. Buenos Aires: Ediciones Jurídicas Europa-América.

Bigio, Jack (1990). «Registros Públicos (Artículos 2008 a 2045 del Código Civil)». En: Exposición de Motivos Oficial del Código Civil, separata especial del diario oficial El Peruano. Publicado el 19 de noviembre de 1990, Lima.

Bullard González, Alfredo (2011). La relación jurídico patrimonial: reales vs. obligaciones, 2. ${ }^{a}$ edición. Lima: Ara Editores.
(2010). Derecho y

economía: el análisis económico de las instituciones legales, 2. ${ }^{\text {a }}$ edición. Lima: Palestra Editores.

Castillo Alva, José Luis (2011). La falsedad documental. Lima: Jurista Editores.

Cuena Casas, Matilde (1996). Función del poder de disposición en los sistemas de transmisión onerosa de los derechos reales. Barcelona: J.M. Bosch Editor.

Dabus Maluf, Carlos Alberto (2007). «Principais limitações ao direito de propiedade no Código Civil de 2002». En: Revista do Advogado, Año XXVII, marzo, (90), pp. 7-21. São Paulo.

Del Solar Labarthe, Salvador (1994). «Protección a terceros adquirientes en el Código Civil: orientaciones y desorientaciones». En: Ius Et Veritas, revista editada por los estudiantes de la Facultad de Derecho de la PUCP, Año V, junio, (8) pp. 159-174. Lima.

Delsol, Jean-Joseph (1878). Explication Élémentaire $d u$ Code Civil. tomo I y II, 3. edición. París: A. Cotillon \& Cie.

Díez Picazo, Luis (2008). Fundamentos del derecho civil patrimonial, tomo III: Las Relaciones Jurídico-Reales, El Registro de la Propiedad, La posesión, 5. ${ }^{a}$ edición. Madrid: Civitas.

Escobar Rozas, Freddy (2001). «Mitos en torno al contenido del derecho de propiedad. Análisis crítico del artículo 923 del Código Civil». En: Ius et Veritas, revista editada por los estudiantes de la Facultad de Derecho de la PUCP, año XI, junio, 22, pp. 106-117. Lima.

Escobar Rozas, Freddy (2004). «El contrato y los efectos reales (Análisis del sistema de transferencia de propiedad adoptado en el Código Civil peruano)». En: Estudios sobre el Contrato en General, 2. ${ }^{a}$ edición, pp. 213-251. Lima: ARA Editores.

Falzea, Ángelo (2006). «El principio jurídico de la apariencia». Traducción de Leysser L. León. En: Derecho PUCP, Revista de la Facultad de Derecho, 59, pp. 177-212. Lima.

Fernández Cruz, Gastón (1994). «La obligación de enajenar y el sistema de transferencia de la propiedad inmueble en el Perú». En: Themis, revista de Derecho, noviembre, 30, pp. 149173. Lima. 
Forno Flórez, Hugo (1993). «El contrato con efectos reales». En: Ius Et Veritas, revista editada por los estudiantes de la Facultad de Derecho de la PUCP, Año IV, noviembre, 7, pp. 77-87. Lima.

García, José Manuel (1993). Derecho Inmobiliario Registral e Hipotecario, tomo I. Madrid: Civitas.

Gete-Alonso, María del Carmen (1997). «El derecho subjetivo (dinámica)». En: Manual de Derecho Civil, tomo I, 2. ${ }^{a}$ edición, pp. 431449. Madrid: Marcial Pons.

Giardina Francesca (2003). Las situaciones jurídicas subjetivas. En Breccia, Umberto; Bruscuglia, Luciano; Busnelli, Francesco; Giardina, Francesca; Giusti, Alberto; Loi, Maria Leonarda; Navarreta, Emanuela; Paladini, Mauro; Poletti, Dianora; y Zana, Mario, Diritto privato, Parte Prima. Turín: Utet.

Gómez Gálligo, Francisco Javier (1996). «Justificación de la calificación registral en el análisis económico del derecho civil: La reducción de los costes de transacción». En: La Calificación Registral, tomo I. Madrid: Civitas.

Gonzales Barrón, Gunther Hernán (2015). La falsificación: Nuevo modo de adquirir la propiedad. Crítica a los tribunales que amparan al tercero que nace del fraude inmobiliario. Lima: Gaceta Jurídica.

(2010). Estudio

Preliminar sobre el Derecho Inmobiliario en el Perú. En: Álvarez Caperochipi, José Antonio, Derecho inmobiliario registral. Lima: Jurista Editores. Pp. 31-161.

(2009). Derechos Reales, 2. ${ }^{a}$ edición. Lima: Ediciones Legales.

(2008)

Introducción al Derecho Registral y Notarial, 2. ${ }^{a}$ edición. Lima: Jurista Editores.

Gordillo Cañas, Antonio (2010). El principio de fe pública registral. Lima: Jurista Editores.

Hardin, Garrett (1968). «The Tragedy of the commons». En: Science, vol. 162, December, 3859, pp. 1243-1248. Utah.
Hernández Gazzo, Juan Luis (1993). «Reflexiones para una propuesta en materia de concurrencia de acreedores». En: Ius Et Veritas, revista editada por los estudiantes de la Facultad de Derecho de la PUCP, Año IV, noviembre, 7, pp. 185-193. Lima.

Hernández Gil, Francisco (1963). «Introducción al Derecho Hipotecario». En: Revista de Derecho Privado. Madrid

Josserand, Louis (1950). Derecho Civil, tomo I, vol. III, La propiedad y los otros derechos reales y principales. Traducción de Santiago Cunchillos y Manterola. Buenos Aires: Bosch y Cía.

Lefevre, Robert (2013). La Filosofía de la Propiedad. Traducción de Juan Manuel González Otero. España: Unión Editorial S.A.

León Hilario, Leysser L. (2007). La Responsabilidad Civil, líneas fundamentales y

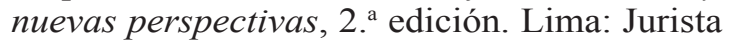
Editores.

Maisch Von Humboldt, Lucrecia (1984). Los Derechos Reales, 3. ${ }^{a}$ edición. Lima: Rocarme.

(1980). «De los

Derechos Reales. Anteproyecto de la doctora Lucrecia Maisch Von Humboldt». En: Proyectos y Anteproyectos de la Reforma del Código Civil, tomo I, pp. 809-891. Lima: Fondo Editorial de la PUCP.

Manzano Solano, Antonio (1991) Derecho inmobiliario registral, vol. II. Madrid: Centro de Estudios Registrales.

Marinoni, Luiz Guilherme (2008). Tutela especifica de los derechos. Traducción de Aldo Zela Villegas. Lima: Palestra Editores.

Mejorada Chauca, Martín (2016). «Propiedad constitucional, a propósito de la fe pública registral». En: Themis, revista de Derecho, agosto, 67, pp. 233-237. Lima.

Mendoza del Maestro, Gilberto (2013). La fe públicaregistralylafalsificacióndedocumentos (Apuntes sobre la legitimación aparente y el poder de disposición). Lima. Consultado el 20 de diciembre de 2015. Recuperado de: http://www.derechoycambiosocial.

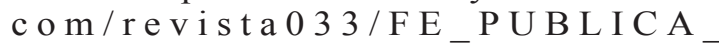
REGISTRAL_Y_FALSIFICACAION.pdf 
Moisset de Espanés, Luis (2004). La publicidad Registral, 4. ${ }^{\mathrm{a}}$ edición. Lima: Palestra Editores.

Morales Hervias, Rómulo (2011). Patologías y remedios del contrato. Lima: Jurista Editores.

Morón Urbina, Juan Carlos (2003). «El nuevo régimen de los actos administrativos en la Ley 27444». En: Comentarios a la Ley del Procedimiento Administrativo General, Segunda Parte, pp.131-172. Lima: Ara Editores.

Nicolò, Rosario (2005). «Las situaciones jurídicas subjetivas». Traducción de Carlos Zamudio Espinal. En: Advocatus, revista editada por los alumnos de la Facultad de Derecho de la Universidad de Lima, 12, pp. 103-116. Lima.

Pais de Vasconcelos, Pedro (2005). Teoria gral do direito civil, $3^{\mathrm{a}}$ Edição, Coimbra: Edições Almedina.

Pau Pedrón, Antonio (1995). Curso de práctica registral. Madrid: Universidad de Comillas.

Petit, Eugene (1983). Tratado elemental de derecho romano. Traducido por José Ferrandez González. Buenos Aires: Editorial Albatros.

Pontes de Miranda, Francisco Cavalcanti (1955). Tratado de direito privado, tomo XI. Río de Janeiro: Borsoi.

Portalis, Jean-Étienne-Marie (2004). Discours préliminaire du premier projet de Code civil. Bordeaux: Éditions Confluences.

Posner, Richard A. (2011). «Savigny, Holmes, y el análisis económico del derecho de posesión». En: Themis, revista de los estudiantes de la facultad de derecho de la PUCP, 48, pp. 55-70. Lima.

Rodotà, Stefano (1986). El terrible derecho. Estudios sobre la propiedad privada. Prólogo y traducción de Luis Díez-Picazo. Madrid: Editorial Civitas.

Roppo, Vincenzo (2007). «Situaciones jurídicas y relaciones jurídicas». En: Derecho de las Relaciones Obligatorias, pp. 46-60. Lima: Jurista Editores.
Rosenvald, Nelson (2006). «A propiedade aparente ni Código Civil de 2002». En: De Iure, revista Jurídica do Ministério Público do estado de Minas Gerais, vol. 6, enero-junio, pp. 303-313. Belo Horizonte.

Salvat, Raymundo M. (1946). Tratado de Derecho Civil Argentino, tomo I, vol. VIII. Buenos Aires: La Ley.

Sierra Vásquez, Guillermo Franklin (2011). La insuficiencia de la buena fe para tutelar a los terceros en las adquisiciones a non domino (tesis para optar el título profesional de Abogado). Universidad Nacional Mayor de San Marcos. Lima. Revisado el 2 de febrero de 2016. Recuperado de: http://cybertesis.unmsm.edu. pe/bitstream/cybertesis/2350/1/Sierra_vg.pdf

Soria Alarcón, Manuel F. (2012). Registros Públicos. Los contratos con publicidad. Lima: Jurista Editores.

Trabucchi, Alberto (1967). Instituciones del Derecho Civil. tomo I. Traducción de Luis Martínez Calcerrada. Madrid: Editorial de Derecho Privado.

Westermann, Harry; Westermann, Harm Peter; Gursky, Karl-Heinz; Eickmann, Dieter (1998). Derechos Reales, vol. I, 7. ${ }^{\mathrm{a}}$ edición. Traductores Ana Cañizares Laso y otros. Madrid: Fundación Cultural del Notariado.

Wolff, Martín (1971). «Derecho de Cosas». En: Enneccerus, Ludwig; Kipp, Theodor y Wolff, Martin. Tratado de Derecho Civil. Traducción de Blas Pérez González y José Alguer, 3. ${ }^{\mathrm{a}}$ edición, tomo III, vol. I. Barcelona: Bosch.

Zatti, Paolo (2005). «Las situaciones jurídicas subjetivas». Traducción de Vladimir Contreras Granda y Gilberto Mendoza del Maestro. En: Revista Jurídica del Perú, Año LV, setiembreoctubre, 64, pp. 357-389. Trujillo: Editora Normas Legales. 